Zeszyty PRASOZNAWCZE

Kraków 2018, T. 61, nr 4 (236), s. 632-659

doi: 10.4467/22996362PZ.18.037.10395

www.ejournals.eu/Zeszyty-Prasoznawcze/

\title{
IGNACY STANISEAW FIUT JAKO RECENZENT I KRONIKARZ ŻYCIA NAUKOWEGO NA LAMACH ZESZYTÓW PRASOZNAWCZYCH
}

\author{
PAWEŁ PŁANETA \\ (1) http://orcid.org/0000-0001-9757-9570 \\ Instytut Dziennikarstwa, Mediów i Komunikacji Społecznej \\ Uniwersytet Jagielloński
}

\section{ABSTRACT \\ Ignacy Stanisław Fiut's media studies reviews and chronicles in Media Issues Quarterly}

The aim of the article is to present the results of the survey on the structure of the media studies publications by Ignacy Stanisław Fiut. An analysis performed in this research was 1) the lexical analysis of I.S. Fiut' the titles of the papers published in 1980-2018 and the content of his reviews and reports (published in the Zeszyty Prasoznawcze - Media Issues Quarterly). The results of statistical evaluations were the words frequency lists, the analysis of certain words concordances and collocations. The effect of such procedure was the reconstruction of important words co-occurrences common patterns. In this phase of the survey the units of analysis were words, so the intensity of the analyzed text attributes were measured by the number and percentage range of certain words. The next phase of the survey was the text mining analysis. Finally, as a result of text mining procedures, the structure of the scientific discourse of I.S. Fiut was reduced to the strongest factors determining which different (detailed) categories have the tendency to co-occur and that is why they create easily distinguishable configuration.

Keywords: Ignacy Stanisław Fiut, media studies, scientific achievements, Media Issues Quarterly, text mining 


\section{Wstęp}

Ignacy Stanisław Fiut - filozof i medioznawca, poeta i ekolog, racjonalista, humanista, wielki miłośnik przyrody i sportu - jako wieloletni kierownik Pracowni Analizy Zawartości OBP w ogromnej mierze przyczynił się do konsolidacji empirycznego (ale też krytycznego) medioznawstwa w Polsce. Jego pasja i wnikliwość zaowocowały nie tylko imponującą liczbą wydawnictw i artykułów naukowych, ale także recenzji oraz sprawozdań naukowych i konferencyjnych.

Naukowcy z Ośrodka Badań Prasoznawczych prowadzili głównie badania stosowane $^{1} \mathrm{w}$ ramach tak zwanej orientacji empiryczno-funkcjonalnej ${ }^{2}$. Model naukowy OBP i Zeszytów Prasoznawczych miał zatem od samego początku wyraźny rys amerykańskiej orientacji postpozytywistycznej. Krakowscy prasoznawcy - jako obserwatorzy świata społecznego - podobnie jak ich koledzy zza oceanu byli zwolennikami poglądu, że wiedzę należy pozyskiwać w drodze badań empirycznych, poszukując obserwowalnych, mierzalnych zjawisk za pomocą weryfikowalnej metody naukowej ${ }^{3}$. Prasoznawcy z OBP nie tyko przyjęli model amerykański, ale przyczynili się do jego upowszechnienia w naszej części Europy. Nie brakowało jednak - co należy podkreślić - wyraźnej refleksji krytycznej wobec opisywanego modelu, co nie wynikało wyłącznie z odmiennej orientacji ideologicznej, lecz było raczej konsekwencją umocowania prowadzonych w Ośrodku badań nad komunikowaniem masowym w europejskiej tradycji filozoficznej ${ }^{4}$ To właśnie do tej racjonalistycznej i krytycznej spuścizny odwo-

1 Co na gruncie amerykańskim, wedle określenia Paula Lazarsfelda, nazwano badaniami administracyjnymi.

2 Analiza funkcjonalna, wedle założeń Roberta Mertona, rozwijana m.in. dzięki niestrudzonej Irenie Tetelowskiej polega na rozpoznawaniu miejsc i ról poszczególnych elementów systemu komunikowania, co ma służyć utrzymaniu równowagi i funkcjonalności systemu, a także na badaniach relacji systemu komunikowania do systemów innych - systemu politycznego, społecznego, systemu kultury etc.

3 W 1984 roku Walery Pisarek zaprezentował rezultaty swych obszernych studiów nad kierunkami i orientacjami w światowych badaniach nad mediami. W konkluzji tej publikacji czytamy, że członkowie zespołu OBP i redakcji Zeszytów Prasoznawczych - pomimo ekspansji metod jakościowych w światowym medioznawstwie - będą nadal zdecydowanie wspierać ilościowe metody i techniki badań. Zwolennicy tak rozumianej metody naukowej w badaniach nad komunikowaniem skłaniają się ku obserwacji empirycznej z uwzględnieniem faktu, że ludzi i ich zachowań nie można uznać za takie same stałe jak elementy świata fizycznego. Chodzi o wyjaśnianie, przewidywanie i kontrolę nad komunikacją. Ontologia orientacji postpozytywistycznej przyjmuje, że świat społeczny istnieje poza naszymi wyobrażeniami na jego temat, a zachowanie ludzkie jest wystarczająco przewidywalne, by można je było badać w sposób empiryczny (nawet jeśli świat społeczny jest bardziej zróżnicowany niż świat fizyczny. Zgodnie z założeniami epistemologicznymi tej teorii, postęp wiedzy odbywa się na drodze systematycznego, logicznego poszukiwania regularności i związków przyczynowych przy wykorzystaniu metody naukowej. I to właśnie metoda naukowa określa aksjologię postpozytywizmu - nieodłączny tej metodzie obiektywizm (a precyzyjniej intersubiektywna sprawdzalność) pozwala oddzielić wyznawane przez badaczy i teoretyków wartości od poszukiwania wiedzy.

4 Spojrzenie krakowskich prasoznawców na amerykańskie koncepcje należy zatem uznać za twórcze i autonomiczne na tle dzisiejszego, nierzadko bezkrytycznego stosunku do importowanych z Zachodu koncepcji naukowych (Płaneta 2017). 
ływał się Ignacy S. Fiut, którego benedyktyńska pracowitość - jako autora badań i publikacji prasoznawczych, ale także kronikarza życia naukowego w kraju i świecie - w połączeniu z imponującą multidyscyplinarną kompetencją walnie przyczyniły się do tego, iż dziś medioznawcy w Polsce mogą się cieszyć długo oczekiwaną suwerennością $\mathrm{w}$ ramach autonomicznej dyscypliny nauki o mediach i komunikacji społecznej.

\section{Ignacy Stanisław Fiut - medioznawca i filozof, artysta, ekolog}

W długoletniej historii kwartalnika OBP Zeszyty Prasoznawcze Ignacy Stanisław Fiut ${ }^{5}$ jest jednym z najczęściej publikujących na jego łamach autorów ${ }^{6}$. Jako autor rozpraw i artykułów ISF zajmował się filozofią mediów $\{134,139\}$, a zwłaszcza problematyką deontologiczną i aksjologiczną $\{065,113\}$. Kiedy w latach 80. i na początku lat 90. XX wieku dopracowywano teorię badań empirycznych nad zawartością prasy, opublikowano pogłębione refleksje nad przyszłością, rozwojem oraz filozoficznymi i poznawczymi podstawami analizy zawartości $\{007\}^{7}$. Przejawem teoretycznych ambicji była wyjątkowa troska prasoznawców z OBP o rozwój metodologii analizy medialnych obrazów świata.

Próbę przedstawienia podstawowych metodologii badań obrazu świata w prasie podjął na łamach kwartalnika w 1985 roku właśnie ISF (wspólnie z Bogusławem Kundą) ${ }^{8}\{002\}$. Wśród wielu artykułów na temat metodologii badań treści w mediach, opublikowanych w Zeszytach, propozycje autora „Kierunków zmian w analizie zawartości" $\{016\}$ mają znaczącą pozycje. Podjął on też ambitną próbę usytuowania metodologii badania treści medialnych w szeregu ewoluujących w czasie teorii poznawczych $\{007\}$ oraz rozważał przyszłość analizy za-

5 W dalszej części tekstu używam skrótowca: ISF.

6 Na łamach Zeszytów Prasoznawczych ISF opublikował do 2018 roku 133 teksty, z czego ponad 100 stanowią recenzje, omówienia i sprawozdania z konferencji i wydarzeń naukowych.

7 Uwaga: w nawiasach klamrowych podano liczby porządkowe odsyłające do prac Ignacego S. Fiuta, które funkcjonują w tekście pt. „Media - filozofia - literatura. Analiza bibliometryczno-dokumentacyjna dorobku Ignacego S. Fiuta za lata 1980-2018" autorstwa Władysława Marka Kolasy i Edyty Gałuszki - w tym numerze, s. 660.

8 „Przez «obraz świata w prasie» rozumieć będziemy sumę informacji o świecie, zawartych $\mathrm{w}$ wypowiedziach prasowych na temat wydarzeń poza granicami naszego kraju lub takich wydarzeń w Polsce, w których uczestniczą ludzie lub instytucje z zagranicy, a w tekstach tym wydarzeniom poświęconych otrzymuje czytelnik - niejako przy okazji - informacje o świecie. [...] Nie mniej ważnym, a może nawet ważniejszym jego elementem jest - obok ogółu informacji o świecie - zbiór reguł wyboru oraz uporządkowania tych informacji, świadomie lub nieświadomie wpisany w sposób redagowania prasy (poszczególnych tytułów), pozwalający w efekcie ująć ów «obraz» jako swego rodzaju strukturę poznawczo-wartościująco-perswazyjną. Struktura ta dzieli się z kolei na elementy przypadkowe i konieczne. Elementami przypadkowymi są informacje o konkretnych wydarzeniach, koniecznymi - sposób (reguły) ich uporządkowania. Stąd pytanie o «obraz świata w prasie» jest nie tylko pytaniem o to, jakie informacje, na temat jakich krajów i wydarzeń pojawiają się w prasie, ale przede wszystkim pytaniem o sposób (reguły) wyboru i porządkowania konkretnych informacji, odpowiedź zaś zakłada rekonstrukcję system kategorialnego, wyznaczającego poszczególnym informacjom miejsce w ogólnej strukturze «obrazu»" \{002, s. 32$\}$. 
wartości, kierunki możliwych jej zmian w kontekście wzrostu znaczenia i liczby przekazów elektronicznych oraz kultury wizualnej.

Pracownia analizy zawartości prasy OBP - pod kierownictwem ISF - wykonywała w ostatniej dekadzie XX wieku liczne badania, których rezultaty prezentowano m.in. na łamach Zeszytów. Zespół kierowany przez ISF skupiał się np. (z perspektywy analizy zawartości prasy) na szczegółowej obserwacji kampanii politycznych mających miejsce podczas kampanii wyborczych $\{014$, 027, 090\}. ISF jest też autorem kapitalnych refleksji filozoficznych poświęconych „utworowi reklamowemu" i jego związkom z dziełem sztuki $\{012\}^{9}$.

ISF zajmował się także innymi, bieżącymi przemianami w polskiej społecznej komunikacji. Od końca XX wieku obserwowaliśmy dynamiczne i głębokie transformacje w systemie mediów. Szczególne zainteresowanie ISF budził segment informacyjnych gazet bezpłatnych. Obraz tych zmian utrwalił na łamach Zeszytów m.in. ISF, który od badań nad początkami polskojęzycznej mutacji sztokholmskiego Metra (na tle jego światowej kariery) \{046, 047\} przeszedł do wnikliwej analizy zmian na rozwiniętym rynku prasy bezpłatnej $\{091\}$, a także obrazu świata na łamach tytułów bezpłatnych $\{132\}$ oraz pisał o przyszłości tego segmentu rynku prasowego w Polsce $\{041\}$.

Duża część publikacji ISF - nie tylko na łamach Zeszytów $\{069,090\}$ - dotyczyła też badań nad rzeczywistością nowych mediów, zwłaszcza nad aktywnością internautów. Na przykład w 2006 roku ISF omówił wyniki badań ankietowych tego dotyczących, które przeprowadzono wśród ponad 600 studentów uczelni krakowskich ${ }^{10}$. Warto dodać, że ISF jest także literatem (poetą i wydawcą, np. Magdalenki Literackiej), ekologiem, miłośnikiem i badaczem sportu.

\section{Media i medioznawstwo wedtug Ignacego S. Fiuta: próba syntezy}

Aby zaprezentować wielką różnorodność zainteresowań badawczych ISF, zebrano tytuły wszystkich publikacji autora z lat 1980-2018. Stworzony w ten sposób korpus A liczy ponad 9 tysięcy wyrazów (tokens - running words), które tworzą około 7 tysięcy haseł (types - distinct words) ${ }^{11}$. Ten zbiór tekstów - jako materiał

\footnotetext{
9 Filozoficzne rozważania doprowadziły ich autora do fenomenologicznego wyróżnienia w ,obiekcie”, jakim jest utwór reklamowy, trzech warstw bytowych: medialnej, dzieła sztuki oraz agitacji reklamowej. ISF rozwijał tym samym koncepcję działa sztuki według Romana Ingardena (1893-1970), światowej sławy filozofa i estetyka, profesora zwyczajnego Uniwersytetu Jana Kazimierza we Lwowie i UJ. Warto nadmienić, że wiele lat wcześniej kierująca Ośrodkiem Irena Tetelowska konsultowała z Ingardenem - i korzystając z jego „Metodologicznego wstępu do teorii poznania”, a także „Studiów z estetyki” i innych prac - podstawowe założenia swej koncepcji prasoznawstwa. Sam Ingarden opublikował na łamach kwartalnika OBP (w 1963 r. w numerze 3) studium pt. „Leopold Blaustein - teoretyk radia i filmu”.

10 Okazało się, iż dla ówczesnych użytkowników sieć stała się medium autotelicznym oraz dobrze rozpowszechnionym i opanowanym $\{065\}$.

11 Wskaźnik TTR (type/token ratio) wynosi 26,47, natomiast standardised TTR std.dev. - 36,17 (przy podstawie standaryzacji wynoszącej 1000 słów).
} 
badawczy - został poddany specyficznej procedurze, w której wzięto pod uwagę zarówno frekwencję pojawiania się określonych wyrazów w poszczególnych jednostkach analizy (tytułach publikacji), jak i ich współwystępowanie w otoczeniu innych wyrazów ${ }^{12}$.

Przedstawiony poniżej schemat 1 należy traktować jako mapę. Zawiera ona 20 obszarów-skupisk wyrazów. Wielkość poszczególnych obszarów na mapie informuje o tym, jak licznie w badanym korpusie dana konfiguracja wyrazów była reprezentowana, natomiast odległości między poszczególnymi obszarami (ale także odległości między poszczególnymi elementami tych obszarów, tzn. wyrazami) informują o tendencjach do ich współwystępowania w badanych jednostkach analizy, czyli tytułach publikacji naukowych ISF.

Owe przedstawione na mapie obszary-skupiska wyrazowe utworzone zostały z wyrazów, które najczęściej pojawiały się w analizowanych tytułach (sprowadzonych na schemacie do form podstawowych). Liczby w nawiasach kwadratowych oznaczają frekwencję danej formy w korpusie A. Średnicę koła wyznaczają zaś liczby jednostek analizy (tytułów) spełniających warunki danej kategorii. Na przykład słowa tworzące kategorię 09. CZLOWIEK wystąpiły łącznie 30 razy w 26 jednostkach analizy (tytułach) prac ISF (np. „Człowiek według Alberta Camusa: studium antropologii egzystencjalnej”) lub napisanych przez niego recenzjach, np. Hoimar von Ditfurth, „Dziedzictwo człowieka z Neandertalu”, recenzja na łamach Zielonych Brygad w 1996 roku.

12 Za pomocą oprogramowania Text Smart obliczono macierz podobieństwa (matrix of similarities) wszystkich przypadków (tytułów). W tym celu dobrano w pary wszystkie wyrazy oraz sprawdzano tendencje do współwystępowania każdego wyrazu z pozostałymi (tzn., jak często każda para wyrazów współwystępuje w poszczególnych tytułach publikacji autorstwa ISF), konstruując tabelę czteropolową (tabelę kontyngencji $-2 \times 2$ contingency table) dla każdej pary wyrazów (litery a, b, c, d reprezentują łączną liczbę jednostek analizy spełniających opisane w nagłówkach rubryk warunki):

\begin{tabular}{|c|c|c|c|}
\hline & & \multicolumn{2}{|c|}{ Kategoria 1 } \\
\hline & & występuje & nie występuje \\
\hline Kategoria 2 & występuje & a & b \\
\hline & nie występuje & c & d \\
\hline
\end{tabular}

Zebrane w ten sposób informacje wykorzystano do obliczenia (dla każdej pary wyrazów) miary podobieństwa Jaccarda, którą wyznacza się w następujący sposób: liczbę wspólnych wystąpień dwóch wyrazów (a) dzielimy przez sumę ich wspólnych wystąpień (a) dodaną do sumy wystąpień każdego wyrazu oddzielnie (b i c):

$$
\frac{a}{a+b+c}
$$

Na tej podstawie wyliczono 20 kategorii, a następnie zakodowano 303 jednostki analizy (tytuły) jako spełniające warunki (wartość $=1$ ) lub niespełniające warunków (wartość $=0$ ) poszczególnych kategorii. W tej formie całość materiału wyeksportowano do programu Statistica celem dalszych obliczeń. Uwaga: $\mathrm{z}$ analizy wyłączono (w formie tzw. excluded list) słowa posiłkowe (w tym niektóre czasowniki), spójniki, zaimki etc. 

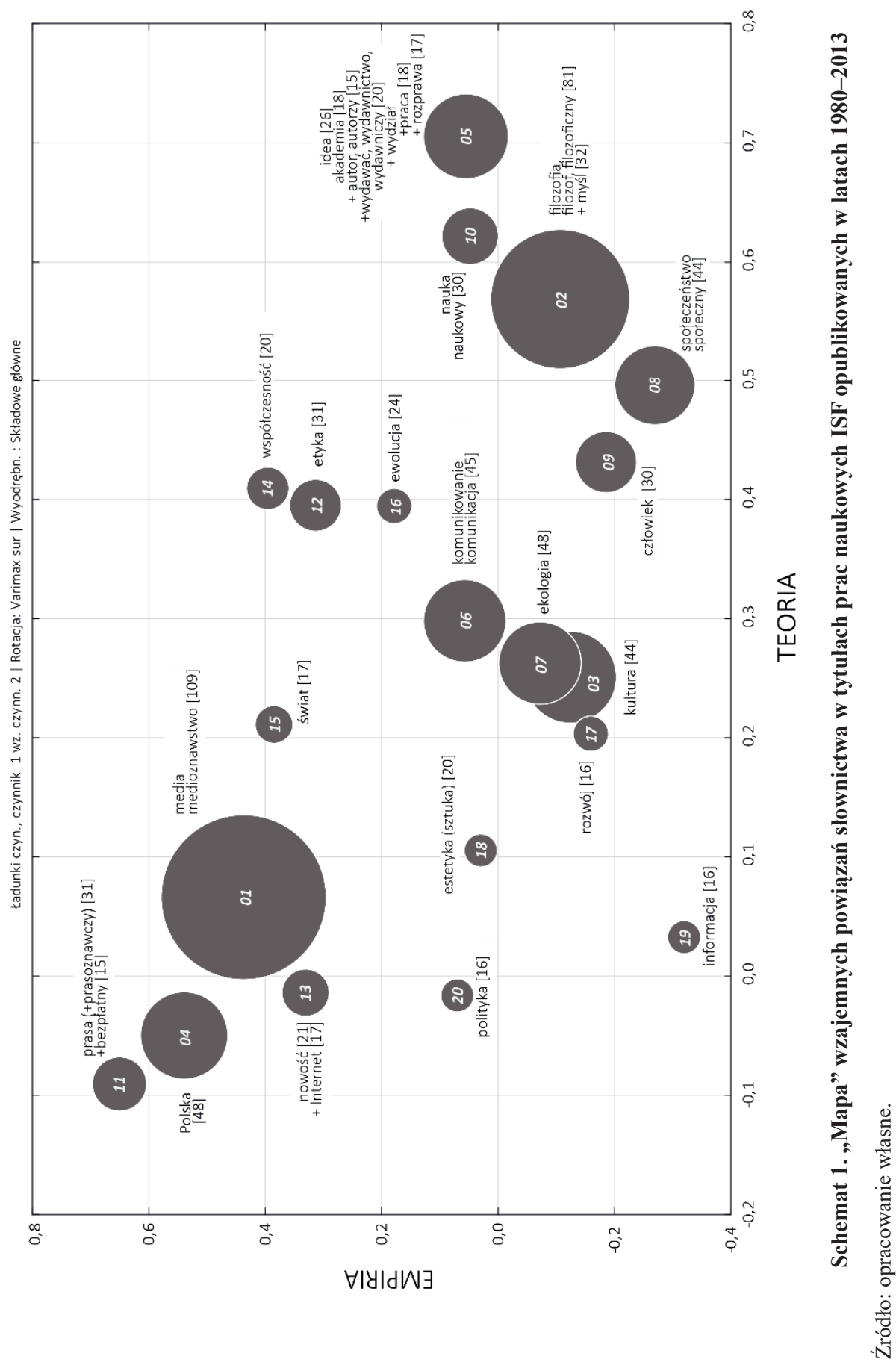
Konfiguracja wzajemnych powiązań słownictwa w tytułach prac naukowych ISF opublikowanych w latach 1980-2013 dowodzi, że obiekty na tej swoistej ,mapie wiedzy" sytuują się na dwóch osiach (wymiarach). Z jednej strony mamy do czynienia $\mathrm{z}$ tekstami, które wiążą się z badaniami empirycznymi. $\mathrm{W}$ tej przestrzeni największa grupa tekstów dotyczy rynku prasy drukowanej (zwłaszcza w Polsce), ale znajdziemy tu także publikacje poświęcone empirycznym badaniom nad Internetem i nowymi mediami. Drugim wymiarem uporządkowania badanych tekstów (na podstawie słownictwa obecnego w ich tytułach) jest wymiar akademicko-teoretyczny, którego obszarem dominującym są teksty z zakresu filozofii mediów. Szczegółowe dane na temat efektów procesu kategoryzacji słownictwa funkcjonującego w tytułach prac naukowych ISF zaprezentowano w tabeli 1.

Tabela. 1. Czołowe kategorie (i ich wzajemne związki) w zbiorze tytułów prac naukowych ISF w latach 1980-2013

\begin{tabular}{|c|c|c|c|c|}
\hline LP. & KATEGORIA & $\begin{array}{l}\text { FREK- } \\
\text { WENCJA }\end{array}$ & \begin{tabular}{|} 
LICZBA \\
JEDNOSTEK \\
ANALIZY \\
$\mathbf{N}=\mathbf{3 0 3}$
\end{tabular} & $\begin{array}{l}\text { WSPÓLCZYNNIKI KORELACJI } \\
\text { MIĘDZY KATEGORIAMI } \\
\text { (TYLKO WSP. KORELACJI } \\
\text { ISTOTNE } \\
\text { Z P }<, 05000)\end{array}$ \\
\hline 01. & $\begin{array}{l}\text { MEDIA (MEDIO- } \\
\text { ZNAWSTWO) }\end{array}$ & 109 & 70 & $\begin{array}{l}\text { 14. WSPÓŁCZESNOŚĆ }\{, 1604, \\
\mathrm{P}=, 005\} \\
\text { 12. ETYKA }\{, 1182, \mathrm{P}=, 040\}\end{array}$ \\
\hline 02. & FILOZOFIA & 81 & 59 & $\begin{array}{l}\text { 05. IDEA, AKADEMIA, } \ldots\{, 3346 \text {, } \\
\mathrm{P}=, 000\} \\
\text { 08. SPOŁECZEŃSTWO }\{, 1156, \\
\mathrm{P}=, 044\} \\
\text { 09. CZŁOWIEK }\{, 1767, \mathrm{P}=, 002\} \\
\text { 10. NAUKA }\{, 3187, \mathrm{P}=, 000\} \\
\text { 12. ETYKA }\{, 1194, \mathrm{P}=, 038\} \\
\text { 16. EWOLUCJA }\{, 1567, \mathrm{P}=, 006\}\end{array}$ \\
\hline 03. & KULTURA & 44 & 39 & $\begin{array}{l}\text { 05. IDEA, AKADEMIA, } \ldots\{, 1939, \\
\mathrm{P}=, 001\} \\
\text { 06. KOMUNIKACJA }\{, 2619, \\
\mathrm{P}=, 000\} \\
\text { 09. CZŁOWIEK }\{, 1286, \mathrm{P}=, 025\}\end{array}$ \\
\hline 04. & POLSKA & 48 & 37 & 11. PRASA $\{, 2737, \mathrm{P}=, 000\}$ \\
\hline \multirow{7}{*}{05.} & IDEA & 26 & \multirow{7}{*}{36} & \multirow{7}{*}{$\begin{array}{l}\text { 02. FILOZOFIA, MYŚL }\{, 3346, \\
\mathrm{P}=, 000\} \\
\text { 03. KULTURA }\{, 1939, \mathrm{P}=, 001\} \\
\text { 06. KOMUNIKACJA }\{, 2183, \\
\mathrm{P}=, 000\} \\
\text { 08. SPOŁECZEŃSTWO }\{, 3219, \\
\mathrm{P}=, 000 \mid \\
\text { 09. CZŁOWIEK }\{, 2153, \mathrm{P}=, 000\} \\
\text { 10. NAUKA }\{, 3833, \mathrm{P}=, 000\} \\
\text { 12. ETYKA }\{, 1331, \mathrm{P}=, 020\} \\
\text { 14. WSPÓŁCZESNOŚĆ }\{, 1666, \\
\mathrm{P}=, 004\} \\
\text { 15. ŚWIAT }\{, 1869, \mathrm{P}=, 001\}\end{array}$} \\
\hline & AKADEMIA & 18 & & \\
\hline & PRACA & 18 & & \\
\hline & ROZPRAWA & 17 & & \\
\hline & AUTORZY & 15 & & \\
\hline & WYDZIAŁ & 14 & & \\
\hline & WYDAWNICTWO & 20 & & \\
\hline
\end{tabular}




\begin{tabular}{|c|c|c|c|c|}
\hline LP. & KATEGORIA & $\begin{array}{l}\text { FREK- } \\
\text { WENCJA }\end{array}$ & \begin{tabular}{|} 
LICZBA \\
JEDNOSTEK \\
ANALIZY \\
$\mathbf{N}=\mathbf{3 0 3}$
\end{tabular} & $\begin{array}{l}\text { WSPÓLCZYNNIKI KORELACJI } \\
\text { MIEDZY KATEGORIAMI } \\
\text { (TYLKO WSP. KORELACJI } \\
\text { ISTOTNE } \\
\text { Z P }<, 05000)\end{array}$ \\
\hline 06. & KOMUNIKACJA & 45 & 35 & $\begin{array}{l}\text { 03. KULTURA }\{, 2619, \mathrm{P}=, 000\} \\
\text { 05. IDEA, AKADEMIA }, \ldots\{, 2183 \text {, } \\
\mathrm{P}=, 000\} \\
\text { 16. EWOLUCJA }\{, 1555, \mathrm{P}=, 007\}\end{array}$ \\
\hline \multirow[b]{2}{*}{07.} & EKOLOGIA & 48 & \multirow[b]{2}{*}{35} & \multirow{2}{*}{$\begin{array}{l}\text { 12. ETYKA }\{, 1774, \mathrm{P}=, 002\} \\
\text { 14. WSPÓŁCZESNOŚĆ }\{, 1276, \\
\mathrm{P}=, 026\} \\
\text { 17. ROZWÓJ }\{, 3459, \mathrm{P}=, 000\}\end{array}$} \\
\hline & PROBLEM & 25 & & \\
\hline 08. & SPOŁECZEŃSTWO & 44 & 34 & $\begin{array}{l}\text { 02. FILOZOFIA, MYŚL }\{, 1156, \\
\mathrm{P}=, 044\} \\
05 . \text { IDEA, AKADEMIA }, \ldots\{, 3219 \text {, } \\
\mathrm{P}=, 000\} \\
\text { 09. CZLOWIEK }\{, 1897, \mathrm{P}=, 001\} \\
\text { 10. NAUKA }\{, 2829, \mathrm{P}=, 000\} \\
\text { 19. INFORMACJA }\{, 3202, \mathrm{P}=, 000\}\end{array}$ \\
\hline 09. & CZŁOWIEK & 30 & 26 & $\begin{array}{l}\text { 02. FILOZOFIA, MYŚL }\{, 1767, \\
\mathrm{P}=, 002\} \\
\text { 03. KULTURA }\{, 1286, \mathrm{P}=, 025\} \\
\text { 05. IDEA, AKADEMIA }, \ldots\{, 2153 \text {, } \\
\mathrm{P}=, 000\} \\
\text { 08. SPOŁECZEŃSTWO }\{, 1897, \\
\mathrm{P}=, 001\} \\
\text { 12. ETYKA }\{, 1413, \mathrm{P}=, 014\}\end{array}$ \\
\hline 10. & NAUKA & 30 & 24 & $\begin{array}{l}\text { 02. FILOZOFIA, MYŚL }\{, 3187, \\
\mathrm{P}=, 000\} \\
\text { 05. IDEA, AKADEMIA, } \ldots\{, 3833 \text {, } \\
\mathrm{P}=, 000\} \\
\text { 08. SPOŁECZEŃSTWO }\{, 2829, \\
\mathrm{P}=, 000\} \\
\text { 12. ETYKA }\{, 1534, \mathrm{P}=, 007\} \\
\text { 14. WSPÓŁCZESNOŚC }\{, 1848, \\
\mathrm{P}=, 001\} \\
\text { 16. EWOLUCJA }\{, 2147, \mathrm{P}=, 000\}\end{array}$ \\
\hline \multirow{2}{*}{11.} & $\begin{array}{l}\text { PRASA (PRASO- } \\
\text { ZNAWSTWO) }\end{array}$ & 31 & \multirow{2}{*}{23} & \multirow{2}{*}{$\begin{array}{l}\text { 04. POLSKA }\{, 2737, \mathrm{P}=, 000\} \\
\text { 13. NOWOŚĆ NOWY }\{, 1246, \\
\mathrm{P}=, 030\} \\
\text { 15. ŚWIAT }\{, 1552, \mathrm{P}=, 007\}\end{array}$} \\
\hline & BEZPŁATNY & 15 & & \\
\hline 12. & ETYKA & 31 & 22 & $\begin{array}{l}\text { 01. MEDIA (MEDIOZNAWSTWO) } \\
\{, 1182, \mathrm{P}=, 040\} \\
\text { 02. FILOZOFIA, MYŚL }\{, 1194, \\
\mathrm{P}=, 038\} \\
\text { 05. IDEA, AKADEMIA, } \ldots\{, 1331, \\
\mathrm{P}=, 020\} \\
\text { 07. EKOLOGIA }\{, 1774, \mathrm{P}=, 002\} \\
\text { 09. CZŁOWIEK }\{, 1413, \mathrm{P}=, 014\} \\
\text { 10. NAUKA }\{, 1534, \mathrm{P}=, 007\} \\
\text { 14. WSPÓŁCZESNOŚC }\{, 3063, \\
\mathrm{P}=, 000\} \\
\text { 17. ROZWÓJ }\{, 1707, \mathrm{P}=, 003\}\end{array}$ \\
\hline
\end{tabular}




\begin{tabular}{|c|c|c|c|c|}
\hline LP. & KATEGORIA & $\begin{array}{l}\text { FREK- } \\
\text { WENCJA }\end{array}$ & \begin{tabular}{|} 
LICZBA \\
JEDNOSTEK \\
ANALIZY \\
$\mathbf{N}=\mathbf{3 0 3}$ \\
\end{tabular} & $\begin{array}{l}\text { WSPÓLCZYNNIKI KORELACJI } \\
\text { MIĘDZY KATEGORIAMI } \\
\text { (TYLKO WSP. KORELACJI } \\
\text { ISTOTNE } \\
\text { Z P }<, 05000) \\
\end{array}$ \\
\hline 13. & NOWOŚĆ, NOWY & 21 & 20 & $\begin{array}{l}\text { 11. PRASA (PRASOZNAWSTWO) } \\
\{, 1246, P=, 030\} \\
\text { 20. POLITYKA }\{, 2581, \mathrm{P}=, 000\}\end{array}$ \\
\hline 14. & WSPÓŁCZESNOŚĆ & 20 & 18 & 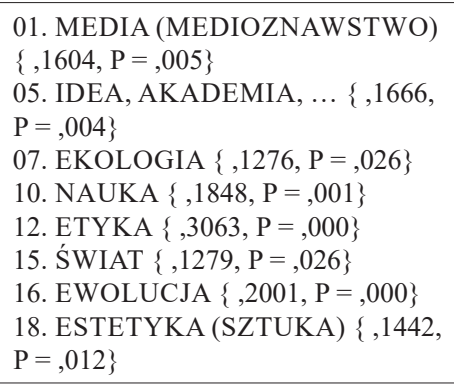 \\
\hline 15. & ŚWIAT & 17 & 16 & $\begin{array}{l}\text { 05. IDEA, AKADEMIA }, \ldots\{, 1869, \\
\mathrm{P}=, 001\} \\
\text { 11. PRASA (PRASOZNAWSTWO) } \\
\{, 1552, \mathrm{P}=, 007\} \\
\text { 14. WSPÓŁCZESNOŚĆ }\{, 1279, \\
\mathrm{P}=, 026\}\end{array}$ \\
\hline 16. & EWOLUCJA & 24 & 15 & $\begin{array}{l}\text { 02. FILOZOFIA, MYŚL }\{, 1567, \\
\mathrm{P}=, 006\} \\
06 . \text { KOMUNIKACJA }\{, 1555, \\
\mathrm{P}=, 007\} \\
\text { 10. NAUKA }\{, 2147, \mathrm{P}=, 000\} \\
\text { 12. ETYKA }\{, 1707, \mathrm{P}=, 003\} \\
\text { 14. WSPÓŁCZESNOŚC }\{, 2001, \\
\mathrm{P}=, 000\}\end{array}$ \\
\hline 17. & ROZWÓJ & 16 & 15 & 07. EKOLOGIA $\{, 3459, \mathrm{P}=, 000\}$ \\
\hline 18. & $\begin{array}{l}\text { ESTETYKA } \\
\text { (SZTUKA) }\end{array}$ & 20 & 14 & $\begin{array}{l}\text { 14. WSPÓŁCZESNOŚĆ }\{, 1442, \\
\mathrm{P}=, 012\}\end{array}$ \\
\hline 19. & INFORMACJA & 16 & 14 & $\begin{array}{l}\text { 08. SPOŁECZEŃSTWO }\{, 3202, \\
\mathrm{P}=, 000\}\end{array}$ \\
\hline 20. & POLITYKA & 16 & 14 & $\begin{array}{l}\text { 13. NOWOŚĆ, NOWY }\{, 2581, \\
\mathrm{P}=, 000\}\end{array}$ \\
\hline
\end{tabular}

Źródło: opracowanie własne.

Teorie i badania medioznawcze $w$ Polsce $i$ w świecie z perspektywy Ignacego S. Fiuta: listy frekwencyjne i słowa klucze

W kolejnej fazie badań wykonanych na potrzeby tego tekstu wykorzystano technikę eksploracyjnej analizy dokumentów tekstowych (określanej jako text mining), którą definiuje się jako zbiór koncepcji, metod algorytmów przetwarzania 
zasobów tekstowych, które - w formie oprogramowania komputerowego - służą zautomatyzowaniu procesów przetwarzania dokumentów sporządzonych w językach naturalnych (Lula 2005, s. 67) ${ }^{13}$.

Celem zastosowania text miningu na potrzeby tego artykułu była identyfikacja powiązań, czyli wykrycie związków istniejących pomiędzy informacjami pozyskanymi ze 100 materiałów autorstwa ISF opublikowanych na łamach Zeszytów Prasoznawczych w latach 1980-2013 w dziale recenzji, sprawozdań i kroniki naukowej. Materiały te - zebrane w korpus B - to ponad 93 tysiące wyrazów (tokens - running words), tworzących prawie 20 tysięcy haseł (types - distinct words $)^{14}$. Po wstępnym opracowaniu i przygotowaniu korpusu B przystąpiono do przeprowadzenia głównej części analizy, w której jednostkami badanymi były całe wypowiedzi (teksty), które poddano procedurze text miningu za pomocą oprogramowania Statistica oraz WordSmith Tools.

Najpierw sporządzono listy frekwencyjne wyrazów pojawiających się w badanych tekstach ${ }^{15}$, co posłużyło rekonstrukcji intensywności określonych treści, tj. tematów, autorów, koncepcji etc. ${ }^{16}$ Informacje o frekwencji i zasięgach procentowych poszczególnych (grup) wyrazów połączono ze słowami kluczami ${ }^{17}$ (wraz

13 Koncepcję text miningu intensywnie rozwijano od końca lat 90. XX wieku. Do jej pionierów zaliczyć należy Marti A. Hearst, która text mining definiuje ,jako proces mający na celu wydobycie z zasobów tekstowych nieznanych wcześniej informacji”. Jak pisze Paweł Lula, „text mining ma charakter interdyscyplinarny, gdyż korzysta ze zdobyczy badaczy zajmujących się data miningiem, uczeniem maszynowym, przetwarzaniem języka naturalnego (a w szczególności osób zajmujących się metodami wyszukiwania i pozyskiwania informacji oraz tłumaczenia maszynowego), statystyką, lingwistyką oraz informatyką" (Lula 2005, s. 68).

14 Wskaźnik TTR (type/token ratio) wynosi 21,69, natomiast standardised TTR std.dev. - 63,53 (przy podstawie standaryzacji wynoszącej 1000 słów).

${ }_{15}$ Przed sporządzeniem listy usunięto wyrazy nieistotne z punktu widzenia dalszej analizy, tj. spójniki, zaimki, wyrazy posiłkowe (konstruując tzw. stop-listę), oraz przekształcono wyrazy pojawiające się w badanych tekstach do ich formy podstawowej. Przy opisywanej transformacji, nazywanej inaczej „redukcją do rdzenia” (ang. stemming), skorzystano ze słownika odmiany języka polskiego PWN (188 450 haseł, tj. types - distinct words, reprezentowanych przez 3911329 form wyrazowych, tj. tokens - running words), który w formie pliku tekstowego implementowano do modułu text mining oprogramowania Statistica. Jako przykład niech posłuży hasło dziennikarz reprezentowane w omawianym słowniku przez formy: dziennikarza, dziennikarzach, dziennikarzami, dziennikarze, dziennikarzem, dziennikarzom, dziennikarzowi, dziennikarzu, dziennikarzy.

16 Wyrazy pochodzące z list odpowiadających poszczególnym dokumentom (jednostkom analizy) połączono w jedną wspólną listę, a następnie zliczono liczbę wystąpień każdego wyrazu w każdym dokumencie. Uzyskane w ten sposób dane utworzyły macierz częstości. W jej wierszach znalazły się kolejne słowa pojawiające się w badanych tekstach, zaś kolumny reprezentowały poszczególne dokumenty (jednostki analizy). Analiza macierzy częstości umożliwiła zbadanie podobieństwa słów oraz dokumentów.

17 Słowami kluczami nie są słowa występujące w danym korpusie najczęściej (z wysokich pozycji listy frekwencyjnej), lecz te, których zasięg występowania w danym tekście jest większy, niż można się tego spodziewać, analizując korpus referencyjny. Najważniejszym elementem analizy słów kluczowych jest właściwy dobór korpusu referencyjnego. Aby określić 'stopień kluczowości' (keyness) danej słowoformy dla danego tekstu (lub zbioru tekstów), bierze się pod uwagę: 1) frekwencję występowania słowoformy w analizowanym tekście, 2) liczbę pozycji na liście frekwencyjnej tekstu analizowanego, 3) frekwencję słowoformy w większym (referencyjnym) tekście, 4) liczbę pozycji na liście frekwencyjnej korpusu referencyjnego. Na liście słowoform kluczowych pojawiają 
z ich kontekstami), co pozwoliło przedstawić wyrazistość (swoistość) określonych wątków podejmowanych przez ISF na łamach Zeszytów na tle całej zawartości kwartalnika ${ }^{18}$.

$\mathrm{Na}$ liście 10 najczęściej pojawiających się pełnoznaczeniowych form wyrazowych w znalazły się słowa:

(1) mediów [472 wystąpienia ${ }^{19}$ ], następnie (2) komunikowania [219], (3) ludzi [206], (4) kultury [177], (5) media [169], (6) informacji [156], (7) pracy [144], (8) rozwoju [134], (9) przekazu [131] oraz (10) autor (129) ${ }^{20}$.

Najsilniejsze związki wyrazowe (clusters) formy mediów to nowych mediów, mediów w Polsce oraz publiczność mediów. W polu konkordancyjnym omawianej formy pojawiają się także następujące słowa: funkcjonowania, rozwoju, oddziaływania, starych (mediów) oraz dziennikarzy, wolności, zawartości. Z kolei słowoforma komunikowania najczęściej pojawia się w takich związkach wyrazowych jak komunikowania się ludzi, a także komunikowania społecznego oraz w procesie komunikowania. Inne częste połączenia to: (komunikowania) medialnego, masowego, ludzi, modelu komunikowania oraz języka ${ }^{21} i$ komunikowania. Natomiast w kontekstach różnych form leksemu kultura pojawiają się wyrazy: ludzi, cyberprzestrzeni, PRL-u $u^{22}$, systemu, konwergencji, komunikowania, polityki, komunikacji, rozwój oraz sztuki, twórcy, teorii i człowieka.

W recenzjach i sprawozdaniach konferencyjnych ISF wśród najczęściej pojawiających się nazwisk są:

się zatem takie wyrazy, które mają nadspodziewanie wysoką frekwencję (lub nadspodziewanie niską) w porównaniu z korpusem referencyjnym.

18 Korpus porównawczy (referencyjny) stanowiła globalna zawartość Zeszytów.

19 Pełne listy frekwencyjne wyrazów badanego zbioru oraz ich konkordancje i kolokacje są dostępne w archiwum OBP.

20 Dalsze miejsca na liście frekwencyjnej - przy liczebności ponad 100 wystąpień - zajmują formy: nowych, komunikacji, języka, badań, życia, reklamy, świata, Polsce oraz publiczności.

21 Problematyka języka mediów i komunikacji - oprócz problematyki filozoficznej (zwłaszcza etycznej), kulturowej (szczególnie artystycznej) i technologicznej (zwłaszcza w kontekście cyfryzacji, sieci i nowych mediów) - zajmowała szczególne miejsce w tekstach recenzyjnych ISF. Warto w tym miejscu wymienić recenzje następujących pozycji: Język w mediach masowych. Pod red. J. Bralczyka i K. Mosiołek-Kłosińskiej. Warszawa, 2000. Rec.: Ignacy S. Fiut; Zeszyty Prasoznawcze. - 2000, nr 3/4, s. 172-173; Polszczyzna 2000. Orędzie o stanie języka na przełomie tysiącleci. Pod red. W. Pisarka. Kraków, 1999. Rec.: Ignacy S. Fiut; Zeszyty Prasoznawcze. - 2000, nr 3/4, s. 172-173; Aitchison, J.: Ziarna mowy. Początki i rozwój języka. Warszawa, 2002. Rec.: Ignacy S. Fiut; Zeszyty Prasoznawcze. - 2003, nr 1/2, s. 171-173; Pisarkowa, K.: Język według Junga. O czytaniu intencji. Kraków, 1994. Rec.: Igor Mostowicz; Zeszyty Prasoznawcze. - 1995, nr 3/4, s. 170-171; Filozofia języka. Oprac. B. Stanosz. Warszawa, 1993. Rec.: Igor Mostowicz; Zeszyty Prasoznawcze. - 1995, nr 1/2, s. 201-203; Pisarek, W.: Polskie słowa sztandarowe i ich publiczność. Kraków, 2002. Rec.: Igor Mostowicz; Zeszyty Prasoznawcze. - 2003, nr 1/2, s. 161-163.

22 Reprezentantem tego związku może być choćby tekst pt. „Polityka kulturalna w prasie PRL” (recenzja pracy T. Mielczarka). Zob. Mielczarek, T.: Od Nowej Kultury do Polityki. Tygodniki społeczno-kulturalne i społeczno-polityczne PRL. Kielce, 2003. Rec.: Ignacy S. Fiut; Zeszyty Prasoznawcze. -2003 , nr 1/2, s. 156-157. 
GOBAN-KLAS, Tomasz (38); McLUHAN, Marshall (23); PISAREK, Walery (23); BRALCZYK, Jerzy (20); FLEISCHER, Michael (17); KLUSZCZYŃSKI, Ryszard W. (15); TOFFLER, Alvin i Heidi (13); POSTMAN, Neil (12); HOPFINGER, Maryla (11); JENKINS, Henry (11); KEANE, John (11); LUHMANN, Niklas (10); KEEN, Andrew (10); BARTHES, Roland (9); BAUER, Zbigniew (9); BUCK, Andrzej (9); GAJDA, Janusz (9); GOULD, Stephen Jay (9); TAPSCOTT, Don (9); BAUDRILLARD, Jean (9); PISARKOWA, Krystyna (8); PFETSCH, Barbara (8); BAUMAN, Zygmunt (7); BARTOSZCZE, Roman (7); DAIMOND, Jared (7); GOLKA, Marian (7); JUNG, Carl Gustaw (7); AITCHISON, Jean (7); POPPER, Karl R. (7); LEVINSON, Paul (7); KAJTOCH, Wojciech (7); KANT, Immanuel (6); ADAMOWSKI, Janusz (6); GODZIC, Wiesław (6); HABERMAS, Juergen (6); HELMAN, Alicja (6); JAROWIECKI, Jerzy (6); WALOSZCZYK, Konrad (6); van DIJK, John (6); DZIKI, Sylwester (6); ARYSTOTELES (5); KORPOROWICZ, Leszek (5); ECO, Umberto (5); JACHNIS, Anna (5); TERELAK, Jan F. (5); MIKUŁOWSKI POMORSKI, Jerzy (5); WALLACE, Patricia (5).

Również na liście słów kluczy najwyższe pozycje (ze względu na wartość współczynnika kluczowości) zajmowały nazwiska badaczy, którym ISF poświęcił w swych recenzjach i omówieniach najwięcej uwagi. Są to - w rankingu opracowanym na podstawie współczynnika $\mathrm{BIC}^{23}$ (wartość podano nawiasach kwadratowych) - kolejno:

GOBAN-KLAS, Tomasz [187] | BRALCZYK, Jerzy [37] | HOPFINGER, Maryla [39] | AITCHISON, Jean [34] | TAPSCOTT, Don [34] | TOFFLER, Alvin (i Heidi) [32] | KEEN, Andrew [32] | POSTMAN, Neil [32] | JENKINS, Henry [30] | KLUSZCZYŃSKI, Ryszard W. [27] | POPPER, Karl [26] | JUNG, Carl Gustaw [25] | BUCK, Andrzej [23] | HELMAN, Alicja [21] | PISARKOWA, Krystyna [20] | PFETSCH, Barbara [19] | KORPOROWICZ, Leszek [18] | WALOSZCZYK, Konrad [18] | FLEISCHER, Michael [16] | DOBEK-OSTROWSKA, Bogusława [16] | HERSHMAN, Lynn [16] | GAJDA, Janusz [15] | GOULD, Stephen Jay [15] | KERCKHOVE, Derrick [14] | KEANE, John [13] | EJCHENBAUM, Borys [12] | STASIAK-JAZUKIEWICZ, Ewa [13] | MCLUHAN, Marshall [13] | DAIMOND, Jared [12] | JACHNIS, Anna [12].

Szczegółowe zestawienie słów kluczowych recenzji, sprawozdań i omówień autorstwa ISF (1980-2013) na tle globalnej zawartości Zeszytów Prasoznawczych przedstawiono w tabeli 2 .

23 W prezentowanej procedurze zastosowano trzy testy statystyczne, w tym test prawdopodobieństwa Dunninga (Dunning's Log Likelihood), który mierzy kluczowość danego wyrazu na podstawie istotności statystycznej i który - zdaniem autora oprogramowania Wordsmith Tools - jest uważany za bardziej odpowiedni niż chi-kwadrat, zwłaszcza gdy porównuje się długie teksty na tle korpusu porównawczego (referencyjnego). Wartość BIC powyżej 10 oznacza bardzo wysoką kluczowość (wysokie prawdopodobieństwo wystąpienia) określonego obiektu (formy wyrazowej) w badanym zbiorze tekstów (Scott 2015). 

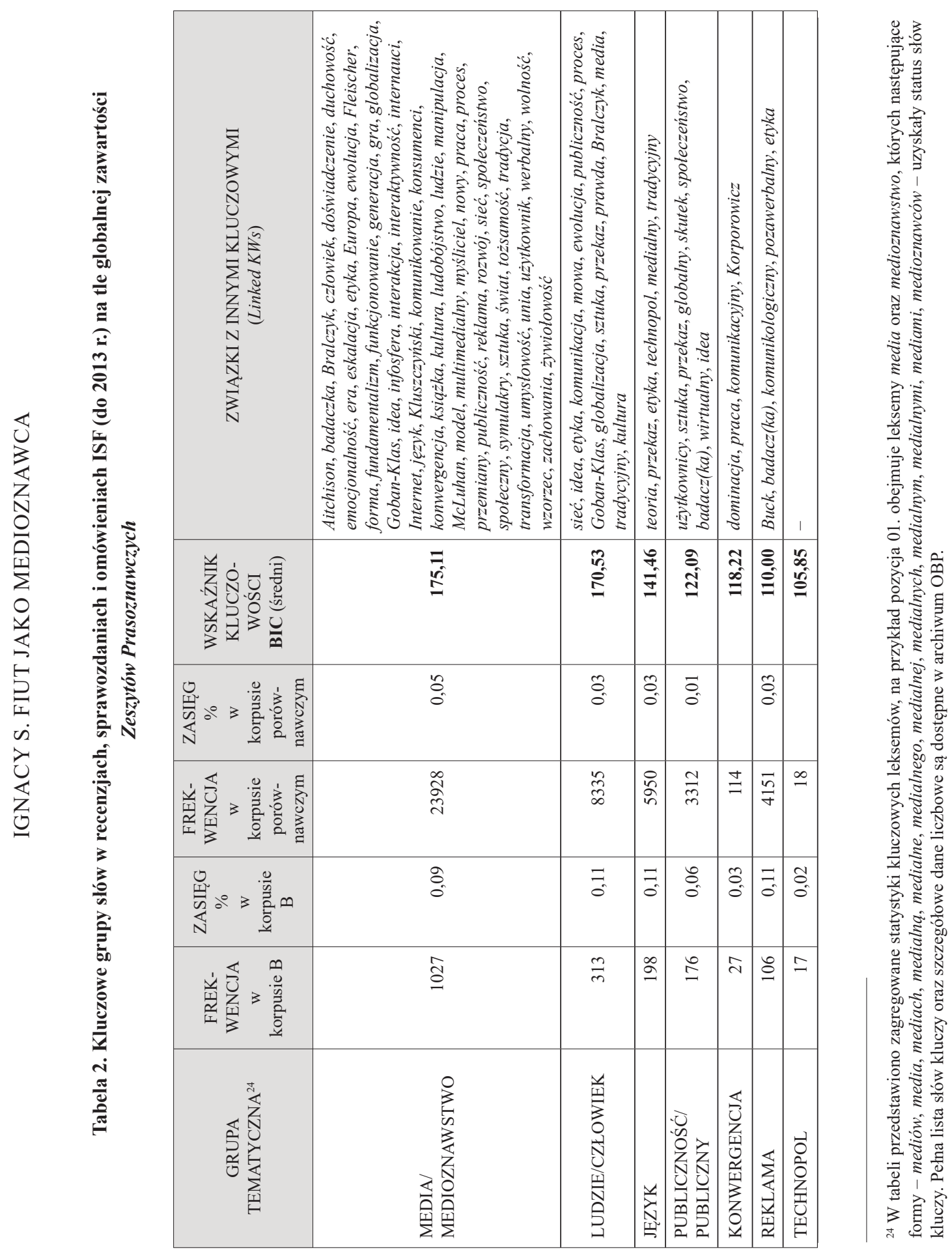


\begin{tabular}{|c|c|c|c|c|c|c|c|c|c|c|c|c|c|c|c|}
\hline 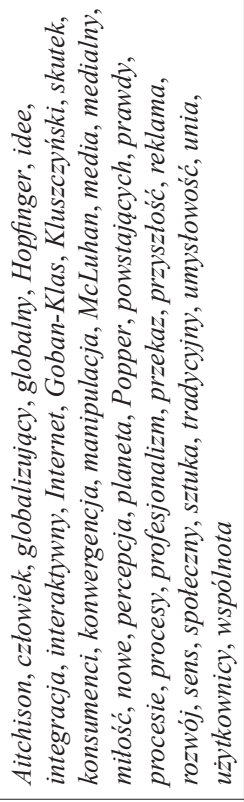 & 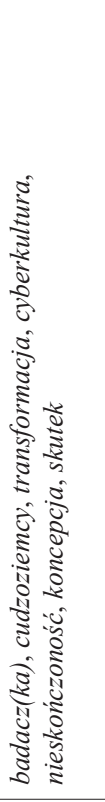 & 1 & 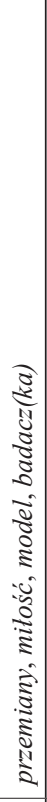 & 1 & 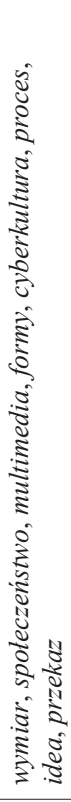 & 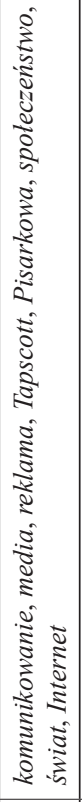 & 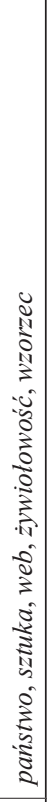 & 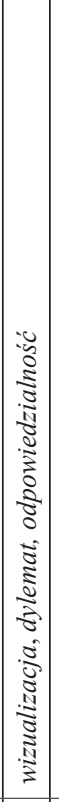 & 1 & 1 & 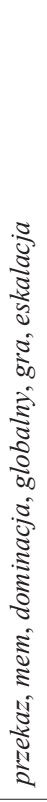 & 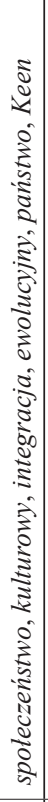 & 1 & 1 & 1 \\
\hline 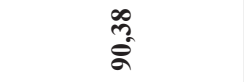 & $\underset{\infty}{\mathbb{\infty}}$ & ڤू. & $\begin{array}{l}\tilde{O} \\
\stackrel{-}{*}\end{array}$ & 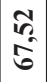 & $\begin{array}{l}\text { f } \\
\text { fं }\end{array}$ & $\begin{array}{l}\stackrel{8}{0} \\
\dot{b}\end{array}$ & $\begin{array}{l}\hat{f} \\
\hat{8}\end{array}$ & $\mid \begin{array}{l}\text { సิ } \\
\text { iิ่ }\end{array}$ & 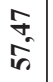 & $\begin{array}{l}0 \\
\text { in }\end{array}$ & $\begin{array}{l}50 \\
\dot{0}\end{array}$ & $\frac{n}{n}$ & $\underset{i n}{\stackrel{f}{n}}$ & $\begin{array}{l}\text { हn } \\
\text { ह̂. } \\
\hat{n}\end{array}$ & $\bar{\sigma}$ \\
\hline$\tilde{o}_{0}^{m}$ & 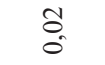 & $\begin{array}{l}\overrightarrow{0} \\
0\end{array}$ & $\begin{array}{l}n \\
0 \\
0\end{array}$ & $\overrightarrow{0}$ & $\begin{array}{l} \pm \\
0 \\
0\end{array}$ & & $\begin{array}{l}\mathrm{T} \\
\delta \\
0\end{array}$ & $\begin{array}{l}0 \\
0 \\
0\end{array}$ & & & & $\begin{array}{l}1 \\
\delta \\
0\end{array}$ & & & \\
\hline 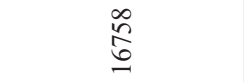 & $\begin{array}{l}\stackrel{\sim}{\mathrm{N}} \\
\text { }\end{array}$ & 辛 & 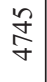 & $\stackrel{\widetilde{\vartheta}}{\stackrel{\mathcal{J}}{\beth}}$ & స్రి & สิ & $\frac{\Re}{\overrightarrow{7}}$ & 扁 & $\underset{\infty}{ \pm}$ & $\frac{\sigma}{m}$ & 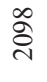 & $\begin{array}{l}\tilde{N} \\
\underset{\sim}{N}\end{array}$ & $\vec{\sim}$ & $\stackrel{\infty}{=}$ & ¿ֶ, \\
\hline$\stackrel{\infty}{\circ}$ & $\stackrel{n}{2}$ & $\begin{array}{l}0 \\
0 \\
0\end{array}$ & $\begin{array}{l}0 \\
0 \\
0\end{array}$ & 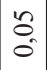 & $\stackrel{0}{\circ}$ & $\hat{\theta}$ & $\begin{array}{l}n \\
0 \\
0\end{array}$ & $\begin{array}{l}\infty \\
0 \\
0\end{array}$ & $\begin{array}{l}\tilde{\theta} \\
\hat{0}\end{array}$ & $\tilde{O}_{0}$ & $\stackrel{+}{0}$ & $\stackrel{n}{0}$ & $\overrightarrow{0}$ & $\delta_{0}^{2}$ & Oे. \\
\hline$\stackrel{\infty}{n}$ & 吕 & $n$ & $\stackrel{\oplus}{-1}$ & in & $\stackrel{\infty}{\Xi}$ & $\stackrel{\infty}{=}$ & $\stackrel{n}{\infty}$ & 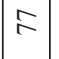 & $\ddot{0}$ & $\stackrel{J}{\sim}$ & $\cong$ & \& & $=$ & $\hat{\sim}$ & ळे \\
\hline 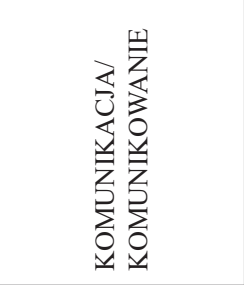 & 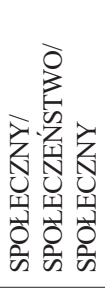 & 至 & 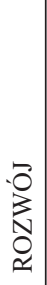 & 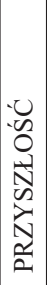 & 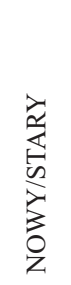 & 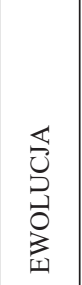 & 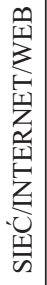 & 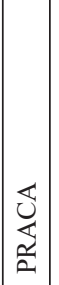 & 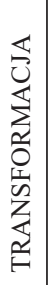 & 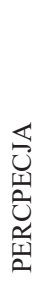 & 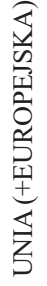 & 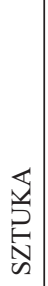 & 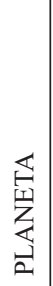 & 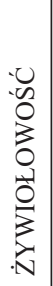 & 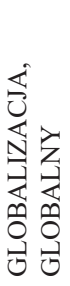 \\
\hline
\end{tabular}




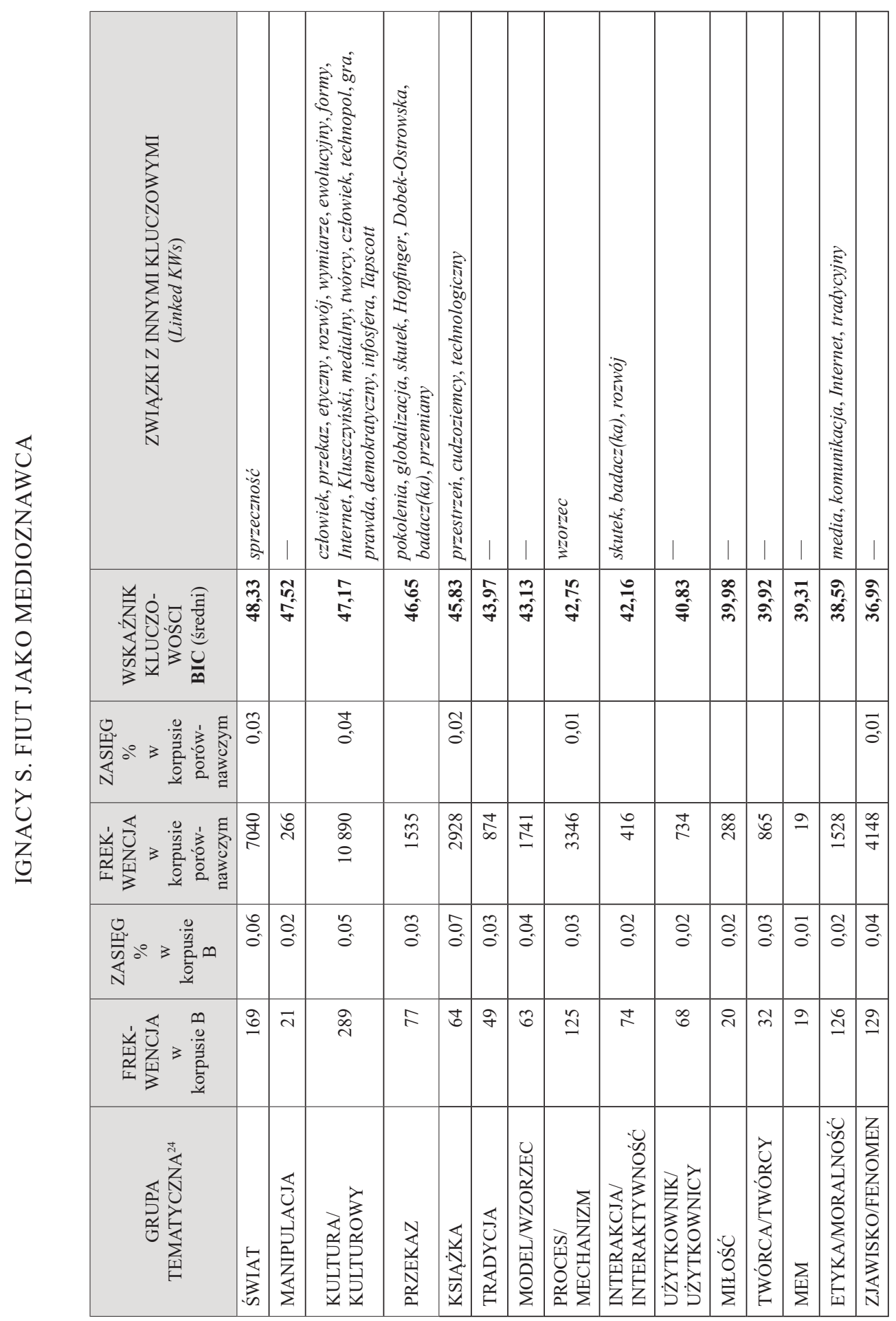




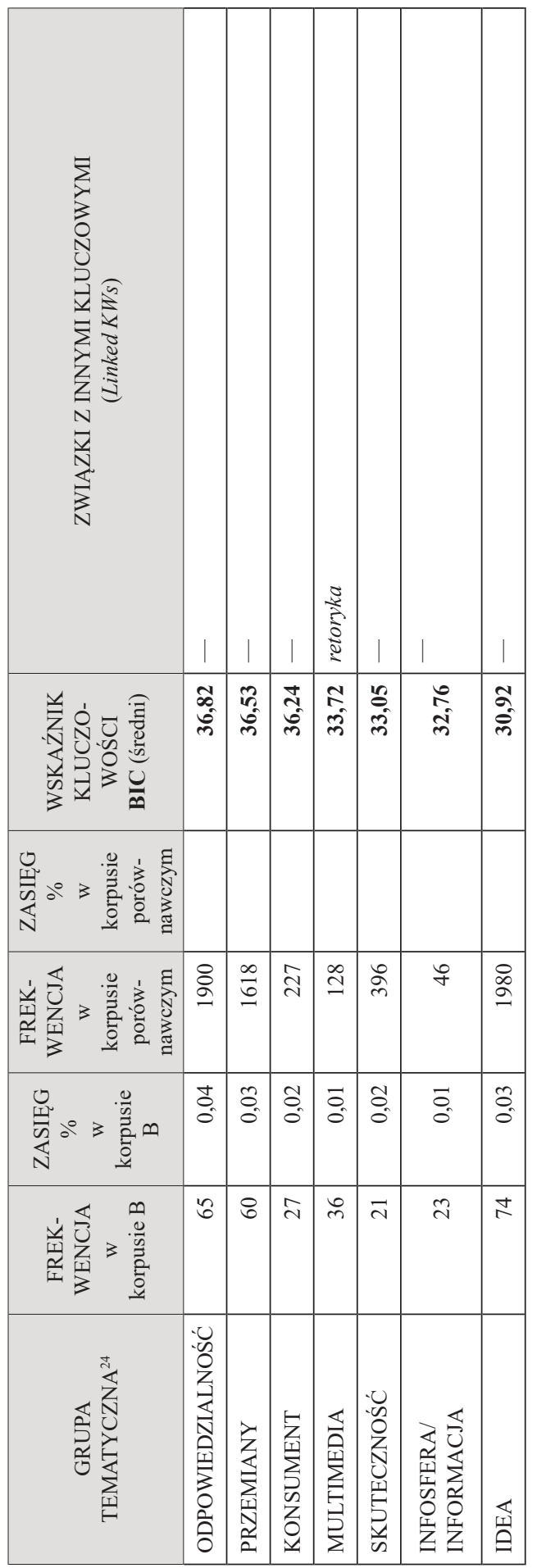

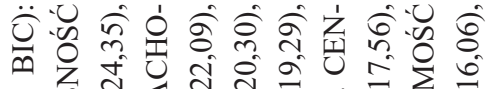

। य

.

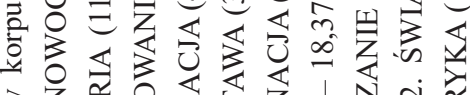

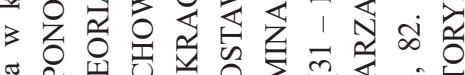

๘

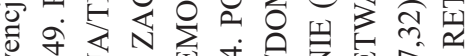

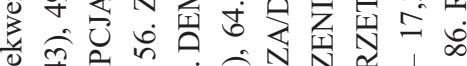

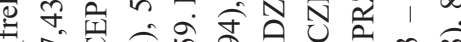

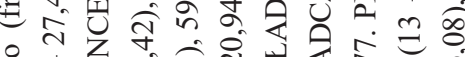

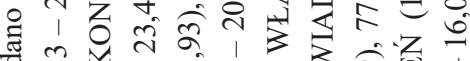

चै थै ते

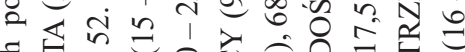

ठै犬

Z

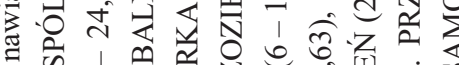

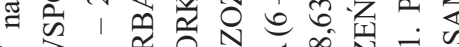

33 e

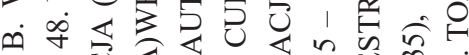

क

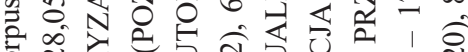

워

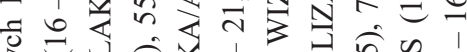

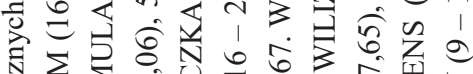

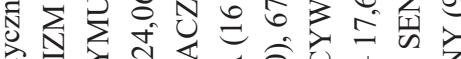

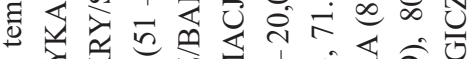

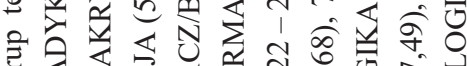

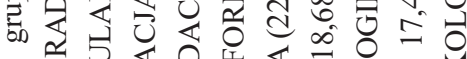

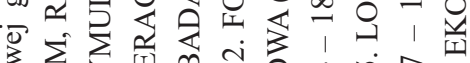

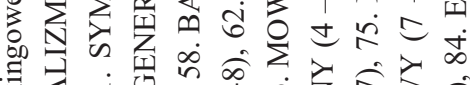

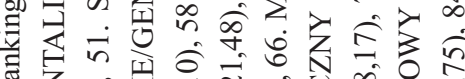

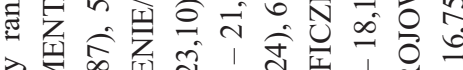

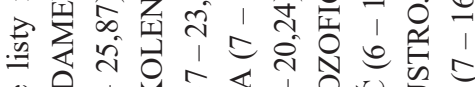

. $\hat{\imath}$ 人

余志包记

¿ ध

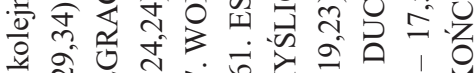

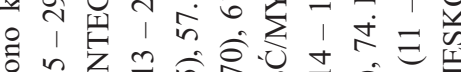

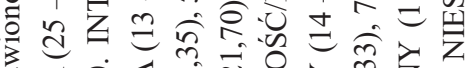

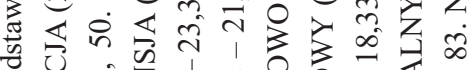

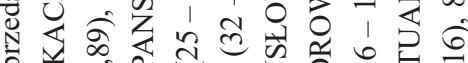
ప

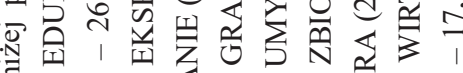
官 


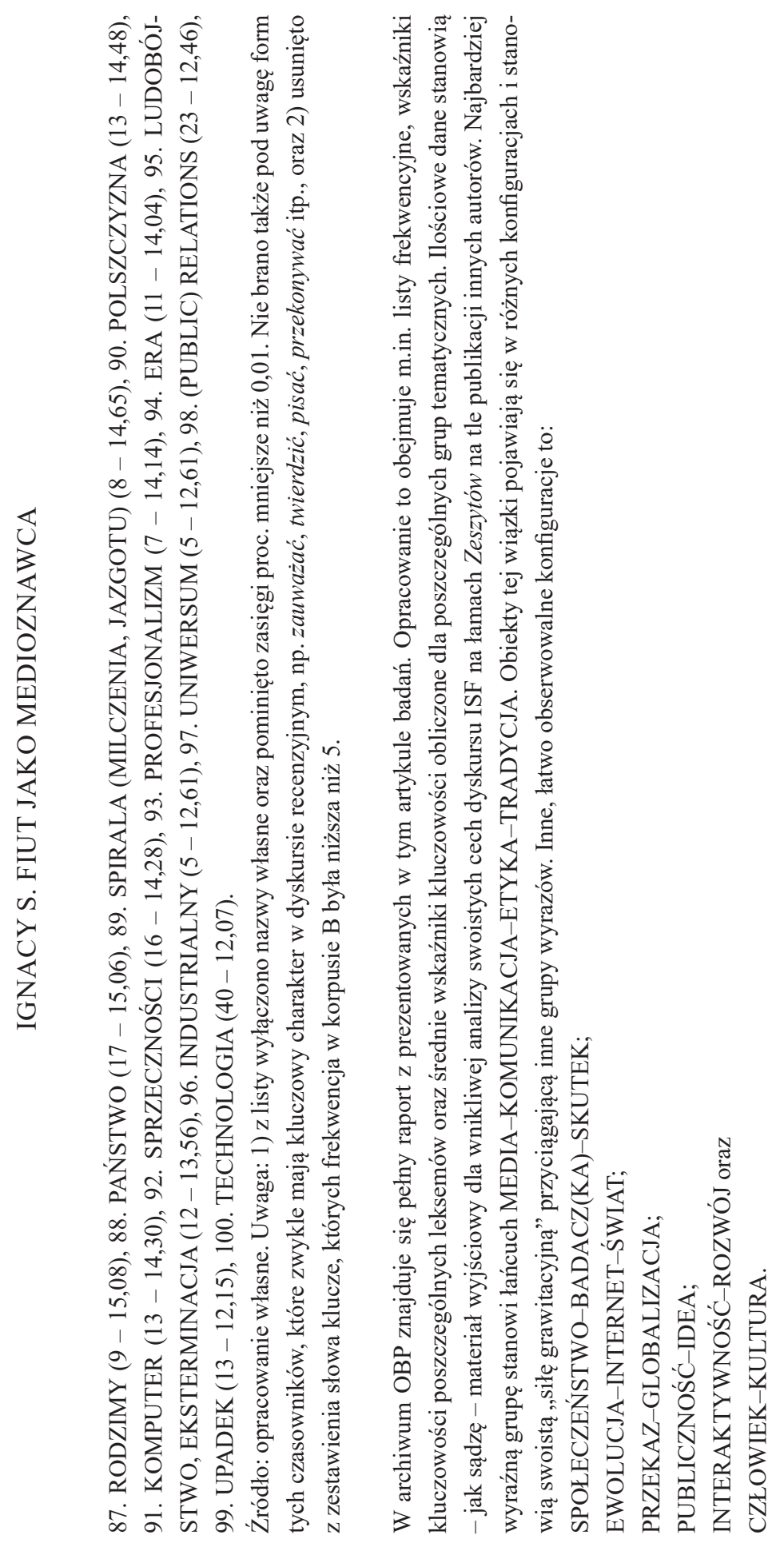




\section{Medioznawstwo w recenzjach ISF : wielowymiarowa struktura wiedzy}

Sporządzona na ostatnim etapie badań matryca wzajemnych korelacji poszczególnych kategorii badawczych oraz wykonane na jej podstawie analizy z zakresu wielowymiarowego wnioskowania statystycznego (analiza skupień oraz czynnikowa) doprowadziły do odkrycia dominujących ram tematycznych medioznawczego dyskursu w tekstach recenzji i sprawozdań oraz rekonstrukcji najważniejszych jego wątków.

Aby wyodrębnić z surowych danych tekstowych najważniejsze tendencje dyskursywne, wykorzystano metodę LSI (Latent Semantic Indexing) i algorytm dekompozycji wartości osobliwej SVD (Singular Value Decomposition) (Lula 2005, s. 79). Współczynniki uzyskane w ten sposób zastosowano następnie do naszkicowania wzajemnych powiązań między 29 elementami przedstawionymi na schemacie 2 . W tym celu skorzystano $\mathrm{z}$ metody aglomeracyjnej, tj. analizy skupień2 ${ }^{24}$.

Kolejność numeracji (zapis rzymski) oddaje „siłę znaczeniową” danego wątku tematycznego (obiektu na schemacie 2), co oznacza, że jeśli w określonym skupieniu pojawia się kilka obiektów (wątków), to ten oznaczony niższą liczbą rzymską jest statystycznie silniejszy. Jeśli zaś dany obiekt występuje osobno (w pewnym oddaleniu od innych), to oznacza, iż jest on z pewnych względów odmienny od innych. Na przykład: najbardziej wyróżniającym się (osobliwym) wątkiem w badanym zbiorze tekstów jest obiekt I (wolność a społeczna odpowiedzialność mediów), natomiast obiekt II (rozważania o perswazji: język reklamy, reklama i propaganda a sztuka, pragmatyka perswazji) niejako „narzuca” dominujące znaczenie pozostałym trzem (VII, XXII oraz XXVII) elementom skupienia.

24 Należy nadmienić, iż w prezentowanej strukturze (schemat 2) poszczególne obiekty (grupy leksemów) mogą się pojawić - choć w różnym natężeniu - w kilku skupieniach jednocześnie, co zmniejsza wprawdzie dystynktywność wyodrębnionych grup tematycznych, ale jednocześnie pokazuje wielowymiarowość pewnych obiektów. 


\section{Schemat 2. Glówne wątki tematyczne recenzji i sprawozdań naukowych autorstwa ISF na lamach Zeszytów Prasoznawczych w latach 1985-2013}

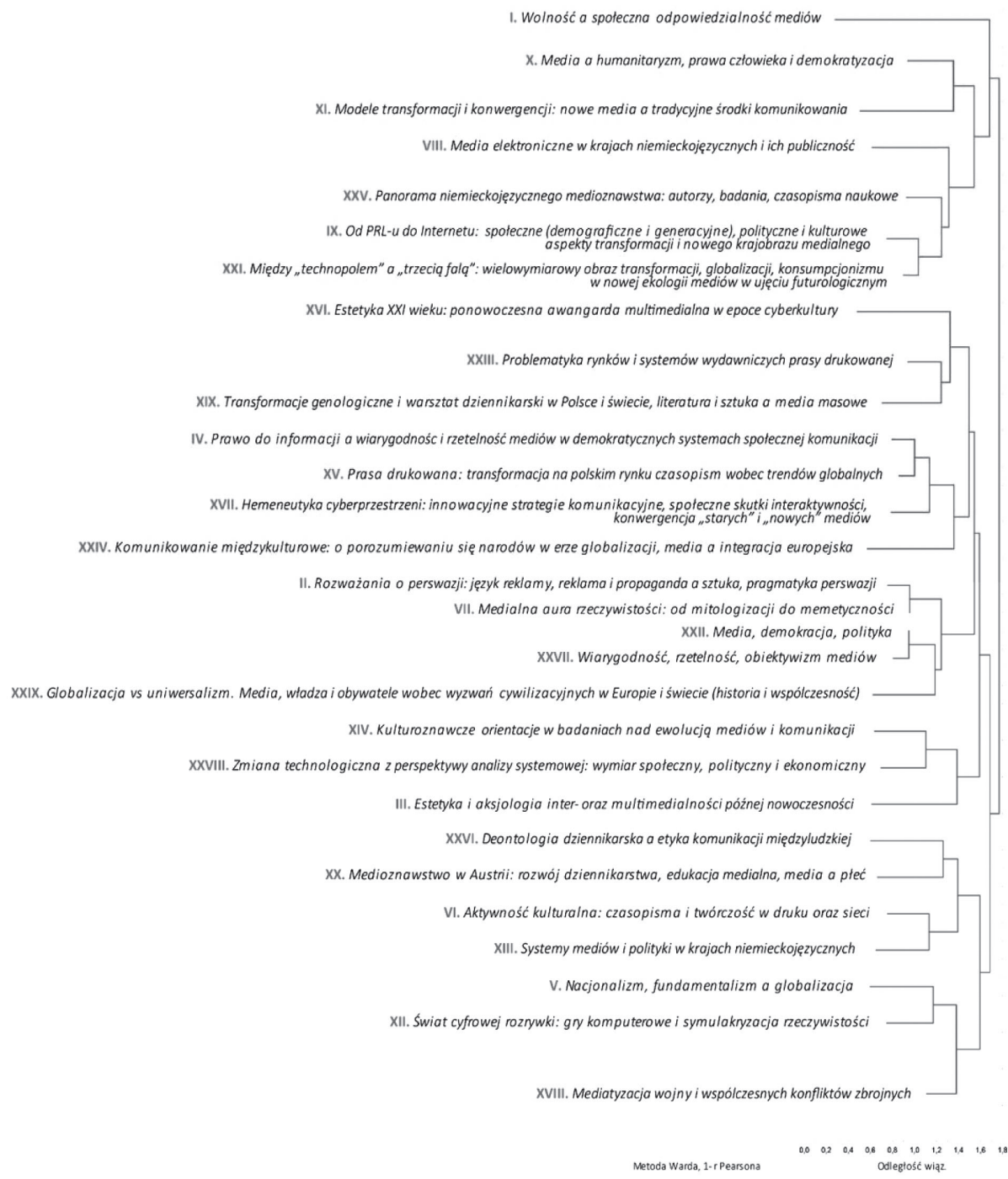

Źródło: opracowanie własne.

Przejdziemy teraz do omówienia najważniejszych tendencji dyskursywnych. [001] Problematyka normatywna komunikacji i dziennikarstwa, a zwłaszcza dylematy wolności i społecznej odpowiedzialności mediów (I) stanowią wyróżniający się wątek w badanym zbiorze recenzji i sprawozdań. W grupie leksemów tworzących ten nurt tematyczny znalazły się - wraz z kluczowym nazwiskiem Tomasza Gobana-Klasa - wyrazy denotujące wymiar etyczny i kul- 
turowy mediów i komunikacji społecznej. ISF pisze na przykład, że mimo transformacji poglądów na temat etyki mediów w kontekście ewolucji mediosfery, nieustannie eksponuje się trzy fundamentalne dla tej przestrzeni etycznej wartości: wolność, odpowiedzialność i profesjonalizm (Fiut 2013). ISF zwraca też uwagę na „siedem grzechów głównych” dziennikarzy, a do powszechnych uchybień etycznych w zawodzie dziennikarza zalicza: dyletantyzm, raperstwo oraz insynuacjonizm, a także besserwisseryzm, pychę, arogancję, chęć posiadania ostatniego słowa, niechęć do dialogu, brak taktu, stronniczość oraz partyjność. ISF pisze m.in. o tym, iż po odzyskaniu wolności (od cenzury) w Polsce nadszedł czas na odpowiedzialność w mediach:

Niczym nieograniczona wolność dziennikarzy oraz mediów jest również [...] niebezpieczna dla nich, bo naraża na procesy i kary sądowe, oraz utratę autorytetu, co ogranicza skuteczne pełnienie misji oraz podstawowe funkcje informacyjne. [...] wydaje się [...] że między wolnością i odpowiedzialnością zachodzi radykalna sprzeczność, lecz skrajne rozwiązania nie są tu właściwe. Przy braku odpowiedzialności, wolność przeradza się mimowolnie w skrajną samowolę, prowadzi do chaosu komunikacyjnego i społecznego, staje się źródłem zła powszechnego, w którym wszyscy mimowolnie uczestniczą. [...] W relacji wolność - odpowiedzialność zachodzą trzy możliwe proporcje. W jednej dominuje całkowicie wolność, w drugiej zbalansowanie wolności i odpowiedzialności, w trzeciej - przeważa odpowiedzialność. Tylko środkową pozycję godzi się uznać za korzystną i zawodowo, i społecznie. Optymalne zatem jest zbalansowanie [...] tych dwóch wartości: nie ma wolności bez odpowiedzialności, nie ma odpowiedzialności bez wolności (Fiut 2013).

Perspektywa normatywna - zwłaszcza problematyka deontologii mediów i komunikacji - zajmuje wyjątkowe miejsce w refleksji medioznawczej ISF. Dlatego też odwołania do etyki znajdują się w licznych publikacjach recenzyjnych, stąd jej obecność w wielu prezentowanych tu nurtach. Gdyby jednak wymienić te publikacje, które stanowią modelowe przykłady namysłu nad etyką dziennikarską, to można wskazać np. „Etos w mediach” (Fiut 1997a), „Etykę a życie publiczne" (Fiut 1998a), a szczególnie niezwykle ciekawe sprawozdanie z konferencji „Problemy etyczne zawodu dziennikarza”, która odbyła się w Poznaniu, w maju 1996 roku (Fiut 1996a).

[002] Media jako kluczowi uczestnicy procesów politycznych, w tym demokratyzacji i upowszechniania praw człowieka (X), współwystępują z szeroko rozumianą problematyką transformacji i konwergencji nowych i tradycyjnych środków komunikowania (XI). W omawianym skupieniu funkcjonują - poza tymi, które tworzą etykiety X i XI - także wiązki leksemów o znaczeniu ogólnym, denotujących życie, kulturę, politykę, prawdę, pracę, model, Europę oraz siec ${ }^{25}$. Wśród licznych tekstów, które można uznać za reprezentanty opisywanego nurtu, znajdują się teksty o meandrach komunikowania politycznego w Polsce po 1989 roku (recenzja pracy Iwony Hofman) (Fiut 2008b), rozważania ISF na temat komunikowania w perspektywie nowych mediów (w formie

25 Dwa kluczowe nazwiska: Jenkins oraz Keen. 
omówienia publikacji Johna van Dijka o społecznych aspektach nowych mediów i sieci) (Fiut 2011), teksty o zagrożeniach dla demokracji i dobrobytu w postaci recenzji „Pułapki globalizacji” Hansa-Petera Martina i Haralda Schumanna (Fiut 2001a).

Dobrym przykładem tekstu osadzonego w nurcie [002] może być omówienie na łamach Zeszytów debaty naukowców, polityków, dziennikarzy i społeczników zorganizowanej w 1997 roku przez Konsulat Generalny Stanów Zjednoczonych w Krakowie oraz Uniwersytet Jagielloński. Jak pisze ISF (pod pseudonimem Igor Mostowicz), dyskusje prowadzone w licznych panelach zdominowała kwestia prymatu etyki nad polityką. Autor zwraca ponadto uwagę na postęp technologiczny w komunikowaniu społecznym, który stwarza zarówno aktorom politycznym, jak i publiczności wiele możliwości bezpośredniego kontaktu, z pominięciem szeregu instytucji demokratycznych:

Daje to oczywiście życiu publicznemu obywateli wiele nowych szans uczestniczenia w nim, które jednak mogą pociągać za sobą rozliczne zagrożenia. Głównie właśnie dlatego na funkcjonowaniu mediów [...] spoczywa szczególna odpowiedzialność za pomyślne funkcjonowanie społeczeństwa demokratycznego nowego typu (Fiut 1998b, s. 199).

W tym samym tekście ISF przestrzega - co dziś jest szczególnie aktualne przed niebezpieczeństwem wykorzystywania mediów jako narzędzi sofistycznej manipulacji i populizmu ${ }^{26}$.

[003] Problematyka transformacji mediów, a zwłaszcza związana $\mathrm{z}$ audiowizualnością, mediami elektronicznymi i ich publicznością w krajach niemieckojęzycznych (VII) łączy się ze słownictwem denotującym panoramę niemieckiego medioznawstwa (wraz z cytowanymi autorami, badaniami i tytułami czasopism naukowych) (XXV) oraz parą wątków IX i XXI. Wątek IX, który umownie nazwano „od PRL-u do Internetu” obejmuje słownictwo denotujące społeczne (demograficzne i generacyjne) oraz polityczne aspekty transformacji i nowego krajobrazu medialnego ${ }^{27}$, natomiast element XXI to wielowymiarowy obraz nowej ekologii mediów w ujęciu futurologicznym ${ }^{28}$.

Dzięki ISF i jego licznym recenzjom oraz omówieniom niemieckich i austriackich publikacji, w tym czasopism naukowych na łamach Zeszytów Prasoznawczych, polscy badacze mieli wgląd - zwłaszcza w latach 90. XX wieku - w stan badań medioznawczych w krajach niemieckojęzycznych. W omawianym skupieniu [003] szczególnie ważne są teksty poświęcone mediom audiowizualnym, np. omówienie zawartości pisma Rundfunk und Fernsehen. Forum der Medienwis-

26 ISF odwołuje się do korzeni demokracji europejskiej, zwłaszcza do Arystotelesa, który politykę rozumiał jako sztukę uzgadniania interesów pomiędzy ogółem grup społecznych składających się na greckie polis, w którym obywatele kierowali się przede wszystkim dobrem publicznym.

27 Tworzą je także leksemy takie jak: dziennikarstwo, władza, sieć, wymiar społeczny, polityka, ludzie, mitologie społeczne, PRL, wolność oraz Tapscott.

${ }^{28}$ W jego skład wchodzą m.in.: polityka, Internet, sieć, komunikowanie, społeczeństwo, globalizacja, życie, konsumpcja, technopol (+ Postman), trzecia fala (+ Toffler). 
senschaft und Medienpraxis (Fiut 1992d, 1993), ale także recenzja pracy Barbary Pfetsch (Fiut 1992c).

W nurcie [003] znajdują się jednak przede wszystkim teksty dotyczące wielowymiarowych przemian medialnych. Są to np.: „Pokolenie sieci nadchodzi” (recenzja książki Dona Tapscotta) (Fiut 2010), „Testowanie trzeciej fali (o koncepcji Alvina i Heidi Tofflerów) (Fiut 1997d), „Obraz użytkownika Internetu w Polsce” (o diagnozie Internetu pod redakcją Krzysztofa Krejtza) (Fiut 2009) i kilkanaście innych pozycji.

[004] Druk w erze cyberkultury to kolejny obszar naukowego dyskursu recenzyjnego ISF. Obejmuje on subdyskurs o ponowoczesności i sztuce multimedialnej w epoce cyfrowej $\left(\mathrm{XVI}^{29}\right)$, stanowiący zresztą wątek odrębny, aczkolwiek w powiązaniu z parą XXIII (problematyka rynków i systemów wydawniczych prasy drukowanej ${ }^{30}$ ) oraz XIX (transformacje genologiczne i warsztat dziennikarski w Polsce i świecie, literatura i sztuka a media masowe ${ }^{31}$ ).

A zatem, w tym nurcie - oprócz tekstu poświęconego przemianom dziennikarstwa i świata mediów, fundamentalnej pracy z 1996 roku, czy omówienia publikacji o transformacji mediów pod redakcją naukową Aliny Słomkowskiej (Fiut 1994b) - znajdziemy wiele innych pozycji, z jednej strony poświęconych zmianie technologicznej (np. „Sztuka ponowoczesna i komunikowanie”) (Fiut 2002), z drugiej zaś, tradycyjnym mediom drukowanym, na tle tychże transformacji, np. teksty pt. „Lubelski region prasowy” (Fiut 2008a), „Książka - 10 lat po transformacji” (Fiut 1999), „Krajowe czasopisma kulturalne” (Fiut 1997b), a także „Czasopisma i pokolenia” (Fiut 1994a).

[005] Dyskurs o głębokich (w tym społecznych, ekonomicznych, a szczególnie kulturowych i cywilizacyjnych) efektach globalizacji obejmuje problematykę prawa do informacji w kontekście prawa do prawdy, czyli refleksję o wiarygodności i rzetelności mediów w demokratycznych systemach społecznej komunikacji (IV ${ }^{32}$ ). Wątek ten jest obecny np. w sprawozdaniu z posiedzenia Krakowskiego Koła Condorceta, które odbyło się w 1992 roku.

29 Funkcjonują tu m.in.: sztuka, aspekt artystyczny, Internet, Polska, działalność wydawnicza, tekst, transformacja, kultura, multimedia oraz publiczność.

30 Wątek pojemny, jeśli wziąć pod uwagę liczbę leksemów, które go tworzą. Są to: dziennikarstwo, technologia, druk, nauka, badania, demokracja, konferencja, wydawnictwo, technologia, badacz, Niemcy, kapitat (zagraniczny), sieć, praca, rynek, książka. Warto w tym miejscu wymienić także artykuł ISF opublikowany na łamach Rocznika Bibliologiczno-Prasoznawczego, t. 6(2014), s. 65-79, pt. „Migracja prasy bezpłatnej do Internetu i jej strategie wydawnicze” oraz sprawozdanie z konferencji „Polski system medialny. Migracje do cyberprzestrzeni”, która odbyła się na Uniwersytecie Jana Kochanowskiego w Kielcach, 21-22 maja 2013 roku (Zeszyty Prasoznawcze - 2013, nr 2, s. 332-333).

31 W tym: przemiany, transformacja, rozwój, wymiar społeczny, masowość, telewizja, audiowizualny, Polska, Europa, świat, gatunek.

32 Tworzą go: polityka, kultura, etyka, prawda, demokracja, informacja, władza, społeczeństwo, prawo. 
W tym samym nurcie znajdują się rozważania o transformacji na polskim rynku dzienników i czasopism (na tle trendów światowych) $\left(\mathrm{XV}^{33}\right)$. Wchodzą w relację z wypowiedziami stanowiącymi próbę konceptualizacji przestrzeni „nowych” mediów (i ich konwergencji z tradycyjnymi środkami przekazu) oraz wnikliwej eksplanacji innowacyjnych strategii komunikacyjnych wywołujących głębokie skutki społeczne $\left(\mathrm{XVII}^{34}\right)$. Szczególnie interesujący jest wątek XVII, który tworzy grupa recenzji najważniejszych prac poświęconych zjawiskom i procesom ze sfery nowych mediów. ISF recenzował m.in. prace Susan Blackmore (Fiut 2003b), Patricii Wallace (Fiut 2001c), Andrew Keena (Fiut 2007) i inne. Wymienione wątki (IV, XV oraz XVII) łączą się z problematyką komunikowania międzykulturowego $\left(\mathrm{XXIV}^{35}\right)$, czyli refleksją na temat porozumiewania się narodów w erze globalizacji (Fiut 2001a). Opisywane skupienie obejmuje ponadto leksemy denotujące procesy związane z integracją europejską (Fiut 1997c, 2003d, 2004a).

[006] Różnorodne rozważania o perswazji: od aksjologii do pragmatyki przekonywania to kolejny nurt dyskursu. Tworzą go dwie pary wątków: II (rozważania o języku reklamy, problematyka reklamy (i propaganda) w kontekście sztuki oraz pragmatyka perswazji ${ }^{36}$ ) i VII (medialna aura rzeczywistości: od mitologizacji do memetyki ${ }^{37}$ ) (Fiut 2003b) oraz XXII (media, demokracja, polityka) (Fiut 1992a, 2001b) i XXVII (wiarygodność, rzetelność, obiektywizm mediów ${ }^{38}$ ). Jak wspomniano, cztery wymienione wątki (których wspólnym mianownikiem jest szeroko rozumiana perswazyjność komunikacji) łączą się z wątkiem XXIX, skupiającym leksemy denotujące problematykę globalizacji (technologii, pieniędzy, sfery technicznej etc.) na tle konfliktów aksjologicznych (np. fikcji uniwersalizmu wartości) współczesnego świata, w tym także dyskurs o środkach przekazu, władzy i obywatelach stojących wobec wyzwań cywilizacyjnych w Europie i świecie, także w ujęciu historycznym ${ }^{39}$ (Fiut 2001d).

[007] Wielowymiarowa refleksja nad różnorodnością medialną i technologiczną w zmieniającej się przestrzeni symbolicznej ludzkiej egzystencji obejmuje subdyskurs XIV, czyli kulturoznawcze orientacje

${ }^{33}$ Polska, globalizacja, wydawniczy, prawda, badania, spoleczny, praca, władza, transformacja, świat.

${ }^{34}$ Tekst, mem, prasa, czytelnictwo, pokolenie, spoteczeństwo, aksjologia, interaktywność, konwergencja, wolność, informacja, hermeneutyka, semiologia.

35 M.in.: komunikacja, globalizacja, polityka, Europa, UE, wolność.

36 Wątek II jest w omawianym skupieniu dominujący. Tworzą go m.in.: język, mowa, reklama, media, prawda, konwergencja, pragmatyka.

37 M.in.: mit, mem, media. ISF pisał o tej problematyce także na łamach Nowej Krytyki (nr 19/2006, s. 141-159) w artykule pt. „Filozoficzne konsekwencje memetyki (ku znaturalizowanej koncepcji umysłu)” oraz w publikacji „Richard Dawkins i jego memetyczna krytyka religii” w zbiorze „Mistrzowie podejrzeń: afirmacja, negacja czy przezwyciężenie?” pod redakcją Jowity Gui, Kraków 2015, s. 75-98.

38 W jego skład wchodzą np.: etyka, odbiorca, nauka, badania.

39 W tym: Internet, życie, Europa, fundamentalizm, media, cudzoziemiec, państwo, demokracja, władza, prawo, obywatelski, emigracja, obcość, historia. 
w badaniach nad ewolucją mediów i komunikacji ${ }^{40}$, oraz subdyskurs XXVIII, tj. namysł nad zmianą technologiczną i jej długofalowymi - społecznymi, politycznymi i ekonomicznymi - konsekwencjami ${ }^{41}$. Współwystępują one z subdyskursem III, problematyką badań nad estetyką i aksjologią (inter-)multimedialności w epoce późnej nowoczesności ${ }^{42}$.

[008] Dwie kolejne pary wątków (XXVI + XX oraz VI + XIII) są elementami składowymi najbardziej różnorodnego skupienia, co ma związek z faktem, iż tworzą go teksty recenzji zawartości niemieckojęzycznych czasopism medioznawczych. ISF wielokrotnie przybliżał polskiemu czytelnikowi treść tychże czasopism naukowych, które - co zrozumiałe - zawierały artykuły o różnorodnej tematyce. A zatem wątek XX, tj. obraz medioznawstwa austriackiego (np. omówienia rozwoju dziennikarstwa w Austrii, edukacji medialnej czy problematyki gender) ${ }^{43}$, łączy się z wątkiem XXVI, czyli deontologią dziennikarską (i szerzej etyką komunikacji międzyludzkiej ${ }^{44}$ ). Wątki XX i XXVI łączą się z parą VI i XIII, czyli - odpowiednio - refleksją nad aktywnością kulturalną (np. problematyką twórczości w druku oraz w sieci ${ }^{45}$ ) oraz tekstami dotyczącymi systemów mediów (zwłaszcza rtv) i polityki w krajach niemieckojęzycznych ${ }^{46}$.

[009] Kolejne skupienie można określić mianem dyskursu nad negatywnymi (lub niezamierzonymi) skutkami procesów globalizacyjnych. Z jednej strony mamy tu do czynienia z problematyką nacjonalizmu, radykalizmu czy fundamentalizmu (np. religijnego) w epoce globalizacji $\left(\mathrm{V}^{47}\right)$ (np. wnikliwe omówienia prac Ernesta Gellnera czy Bassama Tibiego), a z drugiej - co może być pewnym zaskoczeniem - teksty dotyczące negatywnych niejednokrotnie skutków technologicznej rewolucji w świecie cyfrowej rozrywki, tabloidyzacji i symulakryzacji rzeczywistości (XII).

Ostatnim, wyraźnie odrębnym, a jednocześnie w pewnym sensie antonimicznym względem I (normatywnego) jest wątek XVIII obejmujący rozważania nad mediatyzacją wojny i współczesnych konfliktów zbrojnych.

\footnotetext{
40 Np.: komunikacja, kultura, język, badania, teoria.

${ }^{41}$ Poza leksemami wymienionymi w nazwie obiektu w jego skład wchodzą także pojęcia ogólne, takie jak: teoria, życie, badania, praca, nauka, model.

42 Są to także: (trzecia) fala, konferencja, estetyka, badania, Toffler, ludzie, czlowiek, czytelnictwo, wiedza, masowy.

${ }_{43}$ M.in.: prasa, austriacki, sieć, edukacja, kobiecość, Europa, teoria, numer, wypowiedź.

44 M.in.: reklama, język, polityka, etyka, dziennikarstwo, badania, telewizja. Należy podkreślić, że leksemy odnoszące się do etyki mediów funkcjonują także w innych obiektach i skupieniach.

45 Druk, Internet, badania, polityka, komunikacja, Polska, język, kultura, sieć.

46 Telewizja, komunikacja, badania, odbiorca, sztuka, informacja, przekaz, dziennikarstwo, polityka, rozgłośnia, niemiecki.

47 Globalizacja, fundamentalizm, państwo, telewizja, ludzie, prasa, dziennikarstwo, sieć, nowy, Gellner, Tibi.
} 


\section{Zakończenie}

Wszechstronne zainteresowania naukowe Profesora Ignacego Stanisława Fiuta, prezentowane w licznych książkach, artykułach, a także recenzjach i omówieniach, trudno zamknąć w krótkiej formule. Myślę jednak, że filozofia, medioznawstwo, ekologia oraz estetyka stanowią najważniejsze wymiary jego imponującego dorobku.

Autora „Lepszych stron racjonalizmu” poznałem w połowie lat 90. XX wieku. Gdy rozpoczynałem pracę w Ośrodku Badań Prasoznawczych, moim bezpośrednim przełożonym w Pracowni Analizy Zawartości został właśnie Ignacy S. Fiut. Od pierwszego momentu wiedziałem, że mam do czynienia z człowiekiem wyjątkowym: surowym, ale sprawiedliwym szefem, uosobieniem naukowej przenikliwości, empirycznej dyscypliny i sumienności. Szybko przekonałem się także, że Profesor Ignac - jak go po kryjomu nazywaliśmy - jest przede wszystkim dobrym człowiekiem. Kiedy okazało się na przykład, że do czasu przydziału miejsca w hotelu asystenckim nie mam gdzie mieszkać, to Pan Profesor po prostu wręczył mi klucze do własnego mieszkania. Do dziś też pamiętam nasze długie rozmowy medioznawcze i filozoficzne podczas wspólnych podróży „maluchem” Pana Profesora na rodzinną Sądecczyznę, z której obydwaj się wywodzimy, a której piękna przyroda była też niejednokrotnie tematem arcyciekawych opowieści autora „Duchowości ekologicznej”.

Ignacemu Stanisławowi Fiutowi, dociekliwemu epistemologowi i etykowi o budzącej szacunek aparycji greckiego myśliciela, oryginalnemu badaczowi mediów (autorowi nowatorskich i odważnych przed laty, a dziś powszechnie znanych koncepcji, takich jak ,prekampania wyborcza” czy „spirala jazgotu”), wrażliwemu humaniście, ekologowi, miłośnikowi ptaków i innych Bożych stworzeń (m.in. prekursorowi idei międzygatunkowej solidarności), artyście i poecie zawdzięczam bardzo wiele, a zwłaszcza nieopuszczającą mnie po dzień dzisiejszy medioznawczą pasję. Niechże więc ten mój skromny artykuł będzie niedoskonałą, lecz szczerą formą podziękowania dla mojego Mistrza.

\section{Bibliografia}

Hearst M.A. (1999). Untangling Text Data Mining, Proceedings of ACL'99: the 37th Annual Meeting of the Association for Computational Linguistics. University of Maryland, June 20-26, 1999 [http://www.sims.berkeley.edu/ hearst/papers/ac199/acl99-tdm.html; dostęp: 2019-03-05].

Kajtoch W. (2018). Badanie aksjologicznego wymiaru języka prasy. W: A. Szymańska, M. Lisowska-Magdziarz, A. Hess (red.). Metody badań medioznawczych i ich zastosowanie (s. 17-44). Kraków.

Lula P. (2005). Text mining jako narzędzie pozyskiwania informacji z dokumentów tekstowych, s. 67-84 [http://www.stasoft.pl/czytelnia; dostęp: 2019-02-02]. 
Płaneta P. (2016). Ewolucja zawartości Zeszytów Prasoznawczych w świetle wyników badań ilościowych. W: M. Kawka, R. Filas, P. Płaneta (red.). Zeszyty Prasoznawcze. Analiza zawartości (1957-2012). Metody, tematy, autorzy (s. 31-96). Kraków.

Płaneta P. (2017a). Mass Media Research and American Schools of Thought in Zeszyty Prasoznawcze (Media Issues quarterly), Zeszyty Prasoznawcze, t. 60, nr 1(229), s. 70-89.

Płaneta P. (2017b). Struktura wiadomości zagranicznych w nagłówkach New York Timesa w latach 1989-2014. Rocznik Prasoznawczy, t. 11, s. 131-155.

Płaneta P. (2018). Komputerowa analiza tekstu w dyskursach medialnych. W: A. Szymańska, M. Lisowska-Magdziarz, A. Hess (red.). Metody badań medioznawczych i ich zastosowanie (s. 67-90). Kraków.

Scott M. (2015). Wordsmith Tools Manual, https://lexically.net/downloads/version6/wordsmith6.pdf.

Wybrane recenzje i sprawozdania

Fiut I.S. (1992a). Idea wolnej prasy (rec.: J. Keane, Media a demokracja, thum. E. Petrajtis-O’Neill, Londyn 1992). Zeszyty Prasoznawcze, nr 3/4, s. 144-146.

Fiut I.S. (1992b). Prawo do informacji - prawo do prawdy (spr.: Posiedzenie Krakowskiego Koła Condorceta, 22 X 1992 r.). Zeszyty Prasoznawcze, nr 3/4, s. 159-162.

Fiut I.S. (1992c). (Rec.: B. Pfetsch, Politische Folgen der Dualisierung des Rundfunksystems in der Bundesrepublik Deutschland: Konzepte und Analysen zum Fernsehangebot und zum Publikumsverhalten, 1. Aufl. Baden-Baden: Nomos, 1991). Zeszyty Prasoznawcze, nr 1/2, s. $189-191$.

Fiut I.S. (1992d). (Rec.: Rundfunk und Fernsehen. Forum der Medienwissenschaft und Medienpraxis, 1992, nr 1). Zeszyty Prasoznawcze, nr 1/2, s. 192-193.

Fiut I.S. (1993). (Rec.: Rundfunk und Fernsehen 1992, nr 2/4). Zeszyty Prasoznawcze, nr 3/4, s. $175-177$.

Fiut I.S. (1994a). Czasopisma i pokolenia (rec.: A. Buck, Czasopisma literackie młodych 1944 1971, Zielona Góra 1992). Zeszyty Prasoznawcze nr 1/2, s. 197-199.

Fiut I.S. (1994b). Kolejny tom „transformacji” (rec.: Materiały Pomocnicze do Najnowszej Historii Dziennikarstwa. T. 24: Dylematy transformacji prasy polskiej (1989-1993), red. A. Słomkowsa, Warszawa 1994). Zeszyty Prasoznawcze, nr 1/2, s. 199-200.

Fiut I.S. (1995a). Dylematy filozofii języka (rec.: Filozofia języka, oprac. B. Stanosz, Warszawa 1993). Zeszyty Prasoznawcze, nr 1/2, s. 201-203.

Fiut I.S. [Igor Mostowicz] (1995b). Intencyjne podłoże języka (rec.: K. Pisarkowa, Język według Junga. O czytaniu intencji, Kraków 1994) Zeszyty Prasoznawcze, nr 3/4, s. 170-171.

Fiut I.S. [Igor Mostowicz] (1996a). Problemy etyczne zawodu dziennikarza (spr. z konferencji, Poznań 10-11 maja 1996 r.). Zeszyty Prasoznawcze, nr 3/4, s. 194-195.

Fiut I.S. [Igor Mostowicz] (1996b). Przemiany mediów a dziennikarstwo (rec.: Dziennikarstwo i świat mediów, red. Z. Bauer, E. Chudziński, Kraków). Zeszyty Prasoznawcze, nr 3/4, s. $185-187$.

Fiut I.S. [Igor Mostowicz] (1997a). Etos w mediach (rec.: Dziennikarski etos. Z wybranych zagadnień deontologii dziennikarskiej, red. Z. Kobylińska, R.D. Grabowski, Olsztyn 1996). Zeszyty Prasoznawcze, nr 1/2, s. 177-178.

Fiut I.S. (1997b). Krajowe czasopisma kulturalne (rec.: O.K. Szatkowska, P. Bravo, F. Modrzejewski, Czasopisma kulturalne w Polsce 1996/1997. Katalog, Warszawa 1996). Zeszyty Prasoznawcze, nr 1/2, s. 172-173.

Fiut I.S. [Igor Mostowicz] (1997c). Media w Unii Europejskiej (rec.: R. Bartoszcze, Prasa, radio i telewizja w krajach Unii Europejskiej. Cz. 1, Kraków, 1997), Zeszyty Prasoznawcze, nr 3/4, s. 213. 
Fiut I.S. (1997d). Testowanie „trzeciej fali” (rec.: A. Toffler, H. Toffler, Budowa nowej cywilizacji. Polityka trzeciej fali, Poznań 1996). Zeszyty Prasoznawcze, nr 1/2, s. 173-175.

Fiut I.S. (1998a). Etyka a życie publiczne (rec.: Etyka a życie publiczne, red. J. Pawlica, Kraków 1997). Zeszyty Prasoznawcze, nr 1/2, s. 197-198.

Fiut I.S. (1998b). Jak to jest z etycznością polityki (rec.: G. Skąpska, Etyka w polityce, Kraków 1997). Zeszyty Prasoznawcze, nr 1/2, s. 198-199.

Fiut I.S. (1999). Książka - 10 lat po transformacji (rec.: Ł. Gołębiewski, Rynek książki w Polsce. Edycja 1999, Warszawa 1999). Zeszyty Prasoznawcze, nr 3/4, s. 180-182.

Fiut I.S. (2000a). (Rec.: Język w mediach masowych, red. J. Bralczyk, K. Mosiołek-Kłosińska, Warszawa 2000). Zeszyty Prasoznawcze, nr 3/4, s. 172-173.

Fiut I.S. (2000b). (Rec.: Polszczyzna 2000. Orędzie o stanie języka na przełomie tysiącleci, red. W. Pisarek, Kraków 1999). Zeszyty Prasoznawcze, nr 3/4, s. 172-173.

Fiut I.S. [Igor Mostowicz] (2001a). Oblicza globalizacji (rec.: H.-P. Martin, H. Schumann, Pułapka globalizacji. Atak na demokrację i dobrobyt, Wrocław 1999). Zeszyty Prasoznawcze, nr $1 / 2$, s. 145-147.

Fiut I.S. (2001b). Poradniki public relations (rec.: J. Krawulski, Public relations (wybrane zagadnienia), Poznań 2000). Zeszyty Prasoznawcze, nr 3/4, s. 179-180.

Fiut I.S. (2001c). Psychologiczny obraz internautów (rec.: P.M. Wallace, Psychologia Internetu, Poznań 2001). Zeszyty Prasoznawcze, nr 3/4, s. 188-190.

Fiut I.S. (2001d). Społeczeństwo turystów i włóczęgów (rec.: Z. Bauman, Globalizacja i co z tego dla ludzi wynika, Warszawa 2000). Zeszyty Prasoznawcze, nr 1/2, s. 155-157.

Fiut I.S. (2001e). Śmierć robotnikom (rec.: J. Rifkin, Koniec pracy. Schyłek siły roboczej i początek ery postrynkowej, Wrocław 2001). Zeszyty Prasoznawcze, nr 3/4, s. 186-187.

Fiut I.S. (2001f). Wokół postmodernizmu (rec.: B. Dobroczyński, New Age, Kraków 1997). Zeszyty Prasoznawcze, nr 1/2, s. 152-153.

Fiut I.S. [Igor Mostowicz] (2002). Sztuka ponowoczesna i komunikowanie (rec.: R.W. Kluszczyński, Społeczeństwo informacyjne, cyberkultura, sztuka multimediów, Kraków 2001). Zeszyty Prasoznawcze, nr 1/2, s. 191-193.

Fiut I.S. (2003a). Dokąd zmierza ewolucja mowy (rec.: J. Aitchison, Ziarna mowy. Początki i rozwój języka, Warszawa 2002). Zeszyty Prasoznawcze, nr 1/2, s. 171-173.

Fiut I.S. (2003b). Komunikacja a memy (rec.: S. Blackmore, Maszyna memowa, Poznań 2002). Zeszyty Prasoznawcze, nr 3/4, s. 187-189.

Fiut I.S. (2003c). Polityka kulturalna w prasie PRL (rec.: T. Mielczarek, Od Nowej Kultury do Polityki. Tygodniki społeczno-kulturalne i społeczno-polityczne PRL, Kielce 2003). Zeszyty Prasoznawcze, nr 1/2, s. 156-157.

Fiut I.S. (2003d). Problemy polityczne i medialne integracji Polski z UE (spr. z konferencji: Polityka wewnętrzna i polityka zagraniczna w procesie integracji europejskiej, Warszawa 22 listopada 2003). Zeszyty Prasoznawcze, nr 3/4, s. 213-215.

Fiut I.S. [Igor Mostowicz] (2003e). Słowa i ich sztandary (rec.: W. Pisarek, Polskie słowa sztandarowe i ich publiczność, Kraków 2002). Zeszyty Prasoznawcze, nr 1/2, s. 161-163.

Fiut I.S. (2004a). Media a UE (rec.: Media a integracja europejska, red. T. Sasińska-Klas, A. Hess, Kraków 2004). Zeszyty Prasoznawcze, nr 1/2, s. 139-140.

Fiut I.S. (2004b). Unia Europejska w elektronicznych środkach przekazu (spr. z konferencji: Elektroniczne środki przekazu w Polsce wobec rozszerzenia Unii Europejskiej, 5-6 czerwca 2003 w Warszawie). Zeszyty Prasoznawcze, nr 3/4, s. 219-220.

Fiut I.S. (2007). Optymistycznie i pesymistycznie o nowych mediach (rec.: A. Keen, Kult amatora. Jak Internet niszczy kulturę, Warszawa 2007). Zeszyty Prasoznawcze, nr 3/4, s. $181-185$.

Fiut I.S. (2008a). Lubelski region prasowy (rec.: L. Pokrzycka, Prasa w Lublinie (1989-2003). Realia wolnego rynku, Lublin 2006). Zeszyty Prasoznawcze, nr 1/2, s. 193-194. 
Fiut I.S. (2008b). Meandry komunikowania politycznego w Polsce po 1989 roku (rec.: I. Hofman, Polityka, media, społeczeństwo. Studia i szkice, Toruń 2007). Zeszyty Prasoznawcze, nr 3/4, s. 177-179.

Fiut I.S. (2009). Obraz użytkownika Internetu w Polsce (rec.: Diagnoza Internetu 2009, red. K. Krejtz, Warszawa 2009). Zeszyty Prasoznawcze, nr 3/4, s. 196-197.

Fiut I.S. (2010). Pokolenie sieci nadchodzi (rec.: D. Tapscott, Cyfrowa dorosłość. Jak pokolenie sieci zmienia nasz świat, Warszawa 2010). Zeszyty Prasoznawcze, nr 3/4, s. 201-203.

Fiut I.S. (2011). Komunikowanie w perspektywie nowych mediów (rec.: J. van Dijk, Społeczne aspekty nowych mediów. Analiza społeczeństwa sieci, Warszawa 2010). Zeszyty Prasoznawcze, nr 3/4, s. 217-219.

Fiut I.S. (2013). Między wolnością i odpowiedzialnością: poglądy Tomasza Gobana-Klasa na etykę komunikowania. Zeszyty Prasoznawcze, nr 1, s. 40-50.

\section{STRESZCZENIE}

W artykule zaprezentowano wyniki analizy zawartości recenzji, sprawozdań i omówień opublikowanych przez Ignacego Stanisława Fiuta na łamach Zeszytów Prasoznawczych w latach 1980-2013. Początkowym etapem badań była analiza ilościowa korpusu tekstowego. Na tym etapie jednostkę pomiaru stanowił wyraz, a intensywność danych cech tekstu określono za pomocą liczby i zasięgów procentowych występowania poszczególnych wyrazów. Wyniki pomiarów statystycznych ujęto w listy frekwencyjne, które posłużyły badaniom dystrybucji (konkordancji) określonych wyrazów wraz z ich kontekstami. Następnie sprawdzono wybrane kolokacje najistotniejszych wyrazów, co posłużyło rekonstrukcji wzorów współwystępowania określonych wyrazów, a tym samym było podstawą rekonstrukcji wzajemnych związków i wzorów współwystępowania określeń odnoszących się do osób, koncepcji, tematów, problemów obecnych w omawianych recenzjach i sprawozdaniach. W ostatniej fazie badań wykonano komputerową analizę zawartości z wykorzystaniem procedur text mining oraz metodę analizy czynnikowej, co posłużyło wyodrębnieniu głównych wątków dyskursu naukowego w badanych publikacjach recenzyjnych.

Słowa kluczowe: Ignacy Stanisław Fiut, Zeszyty Prasoznawcze, recenzje, sprawozdania, medioznawstwo, analiza zawartości 